Saint Louis University School of Law

Scholarship Commons

All Faculty Scholarship

2011

\title{
Constitutional Rights in the Balance: Modern Exclusionary Rules and the Toleration of Police Lawlessness in the Search for Truth
}

Stephen C. Thaman

Saint Louis University School of Law

Follow this and additional works at: https://scholarship.law.slu.edu/faculty

Part of the Comparative and Foreign Law Commons, $\underline{\text { Criminal Law Commons, and the Criminal }}$ Procedure Commons

\section{Recommended Citation}

Thaman, Stephen C., Constitutional Rights in the Balance: Modern Exclusionary Rules and the Toleration of Police Lawlessness in the Search for Truth (2011). University of Toronto Law Journal, (2011), v. 61, 691-735.

This Article is brought to you for free and open access by Scholarship Commons. It has been accepted for inclusion in All Faculty Scholarship by an authorized administrator of Scholarship Commons. For more information, please contact erika.cohn@slu.edu, ingah.daviscrawford@slu.edu. 
This article explores the tension in modern criminal procedure between the goal of ascertaining the material truth of the criminal charge and the respect for important human rights of criminal suspects during the investigation of their alleged criminal responsibility. It examines two major areas where police run the risk of violating and often do violate the constitutional rights of criminal suspects during interrogations and during invasions of privacy in the form of dwelling searches and interceplion of confidential communications. The approaches of modern democracies to this dilemma run from the strict exclusion of all direct and indirect evidence (fruits of the poisonous tree), whenever a substantial constitutional right is violated, to a discretionary approach, which balances various factors, including the need to ascertain the truth before deciding whether to use the evidence. The ambition of the article is to draw clear lines between when courts should exclude evidence and when discretion can reign.

Keywords: exclusionary rule/fruits of the poisonous tree/nullities/privacy/ search for truth/self-incrimination (privilege of)

\section{Introduction}

The notions of 'truth' and 'evidence' have been inextricably intertwined in the history of Western criminal procedure since the advent of inquisitorial criminal procedure on the European Continent in the late Middle Ages. The justice achieved by early customary and lay courts in pre-inquisitorial times often had little to do with either truth or evidence. The only criminal evidence accepted as being 'true' was the hard facts produced by the flagrant crime, when 'hand-having' thieves or 'red-handed' assailants were caught in the act and either summarily killed or hurriedly sentenced to death by ad hoc courts. Mediation conducted by respected community figures or elders and restoring the peace between victim (or victim's family or clan) and culprit took priority over the meticulous determination of 'what happened' in the era of duels, swearing contests among compurgators, and divine ordeals. There was little truth in these procedures but also little punishment because punishment triggered anger, feud, and blood revenge. Compensation to the victim was the

* Saint Louis University School of Law 
rule, if the suspect was not finished off fragrantly. Even when juries or Schöffengerichte replaced these primitive procedures, their roles had more to do with appraising whether the accused should be accepted back into the community and on what terms than with evidence analysis and truth determination. ${ }^{\prime}$

It was with the 'scientization' of criminal procedure ${ }^{2}$ and the displacement of lay judges and irrational procedures by professional judges with their 'truth-seeking' inquisitorial powers of evidence gathering and preservation that the link between 'evidence' and 'truth' was soldered and took priority over the more humane concern of smoothing over the conflict the wrongful act had caused in the community. The growing ascendency of inquisitorial procedure was dictated by the needs of the central powers of church and state which sought to subjugate local governments and their systems of dispute-resolution. The 'truths' the governments sought to prove through their courts were often self-perpetuating myths or fictions upon which the central powers' domination rested; the crimes which arguably gave rise to this system were crimes against the state or religion that could not be proved adequately by mere witnesses or victims (there were none): they had to be proved by judges learned in the science of the law, acting secretly without being nettled by victims, accuseds, lawyers, or the public. ${ }^{3}$

But the dominance of inquisitorial procedure on the European continent did not, despite advances in evidence taking and greater predictability of professional decision making, mean a humanizing of the resolution of criminal disputes. Enlightenment thinkers complained that more terror and inhumanity were perpetrated by the administration of the law in these times than were committed by common criminals. ${ }^{4}$ More innocent persons were convicted and sentenced to death in this era

1 See in general Stephen C Thaman, 'A Typology of Consensual Criminal Procedures: An Historical and Comparative Perspective on the Theory and Practice of Avoiding the Full Criminal Trial' in Stephen C Thaman, ed, World Plea Bargaining (Durham, NC: Carolina Academic Press, 2010) 297 [Thaman, 'Typology'].

2 The 'right solution' was based on 'textual analysis and logical penetration of its meaning.' Law 'came increasingly to be regarded as a self-contained, or closed system - a 'science'; Mirjan R Damaska, The Faces of Justice and State Authority (New Haven: Yale University Press, 1986) at 31. This science 'needed no illumination' because it was a science of text; Niklas Luhmann, Das Recht der Gesellschaft (Frankfurt: Suhrkamp, 1995) at 48.

3 On how the secret, victimless crime of heresy required a new procedure, see Richard Vogler, A World View of Criminal Jusice (Burlington, VT: Ashgate, 2005) at 25. The procedure in ecclesiastical courts for heresy and magic was the most 'ferocious' and required the forced cooperation of the accused; see Luigi Ferrajoli, Diritto $e$ ragione: teoria del garantismo penale, 5th ed (Rome: Laterza.1998) at 577 [Ferrajoli].

4 Ferrajoli, ibid at 339,382 . On criminal procedure of this epoch as a 'science of horrors,' see ibid at 578 . 
than in any other era of European history, often based on confessions extorted through legalized torture or the threat thereof. ${ }^{5}$

Although torture was officially abolished in Europe by the end of the eighteenth and beginning of the nineteenth centuries, ${ }^{6}$ continental Europe experienced political convulsions throwing most countries back and forth between the extremes of absolute-monarchist police state and liberalism during the nineteenth and early twentieth centuries. All pretences of a state under the rule of law, of course, were erased with the rise of Bolshevism in Russia, Nazism in Germany, Fascism in Italy, and Francoism in Spain.

It was in reaction to the horrors of the holocaust and Soviet totalitarianism that the human rights movement was launched after 1945, resulting in the promulgation of the Universal Declaration of Human Rights (UDHR), ${ }^{7}$ the European Convention on Human Rights (ECHR), ${ }^{8}$ and the International Covenant on Civil and Political Rights (ICCPR). ${ }^{9}$ The American Convention on Human Rights (ACHR) followed in 1969. ${ }^{10}$ After emerging from Fascist domination after World War II, Germany and Italy enacted new constitutions which reflected the priority given to the protection of citizens against the threat of violence and arbitrariness by the state. Spain followed in 1978. A similar explosion of new constitutions and criminal-procedure reforms occurred in the 1990s as Latin America emerged from decades of authoritarian military regimes and the collapse of the Soviet Union and Yugoslavia gave rise to a host of new aspiring democracies in Eastern and South Eastern Europe. It is still too early to predict whether the domino effect of the so-called 'Arab Spring,' which as of this writing has resulted in the toppling of repressive

5 On the conviction of the innocent, Cesare Beccaria, Dei Delitti e Delle Pene, 4th ed (Milan: Feltrinelli, 1995) at 62. Jean de la Bruyère, 'De quelques usage' in Les Caractères, says, 'Torture is a wonderful invention and may be counted upon to ruin an innocent person with a weak constitution and exonerate a guilty person born robust'; and further, 'I might almost say in regard to myself, 'I will not be a thief or a murderer'; but to say, 'I shall not someday be punished as such,' would be to spcak very boldly'; cited in Adhemar Esmein, History of Continental Criminal Pracedure, with Special Reference to France, translated by John Simpson (Boston: Little, Brown, 1913) at $352,380$.

6 John $\mathrm{H}$ Langbein, Torture and the Law of Pmof: Eumpe and England in the Ancien Régime (Chicago: University of Chicago Press, 1977) at 10.

7 Universal Declaration of Human Rights, GA Res 217A (III), UNGAOR, 3d Sess, Supp No 13, UN Doc A/810 (1948) at 71 [UDHR].

8 Convention for the Protection of Human Rights and Fundamental Freedoms, 4 November 1950, 213 UNTS 221, Eur TS 5 [EGHR].

9 Intemational Convenant on Civil and Political Rights, 16 December 1966, 999 UNTS 171, 6 ILM 368 (1967) [ICCP].

10 American Convention on Human Rights, 21 November 1969, 1144 UNTS 143, 9 ILM 99 (1969) [ACHR]. 
dictatorships in Tunisia and Egypt, will extend further and actually lead to a similar democratization and respect for the rule of law.

The experience in common-law countries has been a bit different. England had no experience of Fascism and, due to its unique tradition, no written constitution or Bill of Rights listing specific protections for its citizens. Police lawlessness, where it existed, did not, generally, affect the admission of evidence in the common-law tradition. In Britain, the courts did not worry about the methods used to acquire evidence if it was otherwise relevant and material. ${ }^{11}$

The United States, on the other hand, had its Bill of Rights of 1791, the purpose of which was to restrict the new federal government from passing any laws which would affect the freedoms of the citizens of the thirteen states which made up the new Union at that time. In the early days, however, nearly all criminal cases in the United States were handled in the state courts, governed by state laws and constitutions. Until the end of the Civil War in 1865, African-American slaves had few rights under the laws of the states or the federal government. The enactment of the Fourteenth Amendment to the US Constitution in 1865 granted the freed slaves 'due process of law' in relation to the states, yet it was only in the 1930s that the US Supreme Court (USSC) began overturning state criminal convictions based on torture and rejecting the use of other coercive tactics which undermine the freedom of will of the accused as 'violations of due process. ${ }^{12}$

Already in 1914 the USSC adopted an exclusionary rule which prevented the use of evidence seized by Federal officials in violation of the Fourth Amendment. ${ }^{13}$ The problems this rule addressed were made abundantly clear:

The tendency of those who execute the criminal laws of the country to obtain conviction by means of unlawful seizures and enforced confessions, the latter often obtained after subjecting accused persons to unwarranted practices destructive of rights secured by the Federal Constitution, should find no sanction in the judgments of the courts which are charged at all times with the support of

11 Peter Murphy \& Eric Stockdale, cds, Blackstone's Criminal Practice, 13th ed (London, Blackstone Press, 2003) at 1974.

12 The most notorious of the dozens of cases decided in this area was Brown $v$ Mississippi, 297 US 278 (1936), which involved the torture of Black suspects in a murder case and their hurried sentence to death three days later in a kangaroo jury court.

13 The Fourth Amendment of the US Constitution reads, 'The right of the people to be secure in their persons, houses, papers and effects against unreasonable searches and seizures shall not be violated, and no Warrants shall issue but upon probable cause, supported by Oath or affirmation, and particularly describing the place to be searched and the pcrsons or things to be seized.' 
the Constitution and to which people of all conditions have a right to appeal for the maintenance of such fundamental rights. ${ }^{14}$

The USSC only became a true constitutional court for the entire country, however, when, influenccd by the civil rights movement in the 1950 s and 1960s, it decided that the Fourth, Fifth ${ }^{15}$ and Sixth Amendments ${ }^{16}$ to the US Constitution, were binding on the states, thus enabling it to affect racist practices in many, mainly Southern, states which deprived African-American citizens of the protection of the law in criminal cases.

The notion that evidence obtained as a result of police violation of the constitution could not be used in a criminal trial was finally established nationwide and made applicable to the states during the years that Earl Warren was Chief Justice. ${ }^{17}$ The landmark decisions in this respect were (1) Mapp $v$ Ohio, ${ }^{18}$ which made the Fourth Amendment exclusionary rule of Weeks binding on the States; (2) Wong Sun $v$ United States, ${ }^{19}$ which re-articulated the exclusionary rule in relation to derivative evidence causally linked to preceding constitutional violations; ${ }^{20}$ (3) Massiah $v$ Uniled States, ${ }^{21}$ which provided for exclusion of statements made to government agents by charged defendants, in violation of the Sixth Amendment right to counsel; and, of course (4) Miranda $v$ Arizona, ${ }^{22}$ which provided for exclusion of confessions and admissions made during custodial interrogation where the suspect was not advised of the right to silence and the right to counsel or did not effectively waive those rights, in violation of the Fifth Amendment privilege against self-incrimination.

These landmark decisions, especially Mapp and Miranda, have been very influential overseas, but so have some of the limitations placed on the exclusionary rule by the USSC under Chief Justice Warren Burger, ${ }^{23}$ foremost of these being the exceptions to the doctrine of the 'fruits of

14 Weeks v United Slates, 232 US 383 at 392 (1914) [Weeks].

15 US Const amend $\mathrm{V}$ provides inter alia that '[n]o person ... shall be compelled in any criminal case to be a witness against himself.'

16 US Const amend VI, inter alia: 'In all criminal prosecutions, the accused shall have the Assistance of Counsel for his defense.'

17 From 1953 to 1969.

18 Mapp v Ohio, 367 US 643 (1961) [Mapp].

19 Wong Sun v United States, 371 US 471 (1963).

20 The term 'fruit of the poisonous tree' was originally coined by Justice Frankfurter in Nardone $v$ United States, 308 US 338 (1939), but the idea that the government could not use derivative evidence was articulated nineteen years earlier by Justice Holmes in Silverthorne Lumber Co v United Stales, 251 US 385 (1920) [Silverthome].

21 Massiah v United States, 377 US 201 (1964).

22 Miranda v Arizona, 384 US 436 (1966) [Miranda].

23 Warren Burger was Chief Justice of the USSC from 1969 to 1986. 
the poisonous tree' known as 'inevitable discovery'24 and 'independent source' ${ }^{25}$ and the 'good faith' exception to violations of the Fourth Amendment. ${ }^{26}$

Long before the innovations of the Warren Court, inquisitorial systems on the European continent had developed rules to address violations of the law by organs of law enforcement at a time when common-law courts never questioned the provenance of the evidence before them. Continental European codes of criminal procedure prescribed rather strict rules for the gathering of evidence and the performance of other acts during the preliminary criminal investigation and provided for the nullification of the efficacy of these acts if they were performed in violation of the statutory rules. So-called 'nullities' could and did lead to exclusion of evidence. ${ }^{27}$ In fact, one of the most influential treatises on exclusionary rules was written in Germany before the USSC's decision in Weeks $s^{28}$ and is one of the first scholarly attempts to create a balancing test for the introduction of illegally gathered evidence.

The thesis of this article is that, while all lawmakers and courts 'balance' that is, make value judgments - when navigating between the Scylla of fundamental or constitutional rights and the Charybdis of truth and accuracy in criminal trials, some kinds of official law violations are so serious that they should trigger a very strong presumption of non-use of the evidence resulting therefrom. True 'balancing' of various considerations should occur only where the violation is not properly characterized as fundamental.

The value judgment that a violation is fundamental is sometimes made at the level of international law, such as with the prohibition of torture, sometimes in constitutions and codes, and sometimes by the courts. The prevailing view is that the violations must be 'serious'; that is, must be of fundamental or constitutional rights. Even if a constitutional violation has been identified which could trigger exclusion or 'non-use' of evidence, judges must again decide whether the evidence the prosecution seeks to use is actually the 'fruit of the poisonous tree'; that is, does it derive inexorably from the constitutional violation? And finally, even if it is agreed that a constitutional right has been violated and the evidence sought to be admitted is the fruit thereof, some jurisdictions still require the judge to engage in a balancing of other important interests before deciding on admissibility, for instance: (1) the

24 First articulated in Nix $v$ Williams, 467 US 431 at 444-50 (1984) [Williams].

25 First articulated in Silverthome, supra note 20 at 392 but then reaffirmed in Murray $v$ United States, 487 US 533 at 537-9 (1988) [Murray].

26 United States $v$ Leon, 468 US 897 at 918-25 (1984) [Leon].

27 On how inquisitorial Europe developed 'extrinsic' exclusionary rules relating to 'values unrclated to the pursuit of truth' at a time when the common law only knew 'intrinsic' rules relating to the probative value of evidence, see Mirjan R Damaska, Evidence Law Adrift (New Haven, CT: Yale University Press, 1997) at 12-7.

28 Ernst Beling, Die Beweisverbote als Grenzen der Wahrheitserforschung im Strafprozess (Breslau, Germany: Schletter'sche Buchhandlung, 1903) [Beling]. 
seriousness of the constitutional violation (was it intentional, reckless, negligent, etc), (2) the gravity of the crime which is before the court, (3) the character of the evidence subject to exclusion (its credibility, importance for proving guilt, whether it constitutes the compus delicti of the crime or is 'mere evidence,' etc), (4) whether use of the evidence would violate the defendant's right to a fair trial, and other factors.

While courts will inevitably engage in balancing, I do not think that determining the material truth in a criminal proceeding should be considered to be a higher goal than respect for the international and constitutional protection of the right to human dignity and related guarantees respecting the right to silence and privacy. But the principle of material truth, which I believe nowhere has constitutional status, still holds sway in the criminal courts. Yet, a legal system which takes advantage of explicit loopholes or vague balancing principles in order to use evidence gathered directly or indirectly by means of unconstitutional acts of its investigative organs only with difficulty incorporates the spirit of a state under the rule of law. As long as such loopholes exist, constitutional rights will be routinely violated by state officials.

A dismissal or acquittal in a criminal proceeding violates no fundamental human rights, cven when the evidence seems to point to the guilt of the accused. The victim of an act of violence or theft remains a victim, whether or not the defendant is convicted. In the case of victimless drug crimes, which constitute the overwhelming majority of cases involving illegal searches and a large number of those with illegal wiretaps, a dismissal does not prevent future surveillance and legal apprehension of what are usually repeat offenders involved in an illegal enterprise.

In the United States, the power in the hands of law enforcement is awesome. Life imprişonment is possible for first-time drug dealers ${ }^{2 y}$ and recidivist thieves. ${ }^{30}$ Around 751 of every 100,000 residents of the United States are behind bars. ${ }^{31}$ The coercive nature of the plea-bargaining system means that no more than 5 per cent of those convicted actually have a trial that results in an ascertainment of 'the truth' based on the full panoply of 'due process' rights. ${ }^{32} \mathrm{~A}$ healthy scepticism if not mistrust of the powers of the state, even in a modern democracy, may still be warranted and the warnings of the authors of the Weeks and subsequent decisions should not be dismissed as being antiquated..$^{39}$

29 Harmelin v Michigan, 501 US 957 (1991).

30 Ewing v Califormia, 538 US 11 (2003); Lockyer v Andrade, 538 US 63 (2003).

31 Adam Liptak, 'Inmate Count in US Dwarfs Other Nations' New York Times (23 April 2008) Al.

32 Thaman, 'Typology' supra note 1 at $327-8$.

33 I disagree with the majority of the USSC when they intimate that improved police training, discipline regimes, and the possibility of civil suits (which were not available when Mapp, supra note 18 was decided) might make the exclusionary rule no 
In order to provide an effective remedy for violations of rights in criminal investigations, evidence obtained in violation of fundamental constitutional rights should presumptively be excluded, subject only to narrowly drawn exceptions for good-faith errors and emergencies. Exclusion of such evidence șhould not depend on the balancing of interests; otherwise, fundamental human rights will be lost in the balance. But evidence obtained through unlawful state conduct that does not rise to the level of violating a fundamental constitutional right may properly be considered for admission on the basis of a balancing test. To illustrate this distinction, I will concentrate on violations of two of the most important constitutional protections; that is, (1) where police violate the constitution in acquiring confessions, and (2) where they violate the constitution by invading the privacy of one's home or private conversations. ${ }^{34}$ I will analyse the constitutional, statutory, and court-made doctrine dealing with seemingly absolute exclusionary rules in comparative and international law, which brook of no balancing (or are 'pre-balanced' by the law-giver), and relative exclusionary rules, which encourage balancing of various interests, and will explore how these absolute and relative exclusionary rules deal with the use of derivative evidence or 'fruits of the poisonous tree.' Before beginning my analysis of the various approaches, however, I will briefly discuss the concept of 'nullities' as it developed in civil-law jurisdictions and try to flush out how 'nullities,' in the abstract, differ from modern exclusionary rules. The workings of concrete 'nullities' and exclusionary rules will then be addressed in the succeeding parts of the article.

\section{II 'Nullities' in modem criminal procedure codes}

Many countries in Europe and Latin America still provide for 'nullities' when there is a violation of procedural norms. In some countries, such as France, procedural 'nullities' are still the only statutory grounds for excluding evidence. In others, such as Italy, Spain, Brazil, or Colombia,

longer valid. Hudson v Michigan, 547 US 586 at 597-9 (2006) [Hudson]. The economic crisis has caused drastic cuts in the budgets of police departments (as well as public defender offices) which could lead to an actual decline in the quality of justice delivered on both the investigative and the adjudicative ends of criminal proceedings in the United States. And violations of constitutional rights, such as failure to get a scarch warrant, are often just cost-cutting and time-saving measures not linked to any true exigent circumstance.

34 I will be largely ignoring another substantial area of exclusionary doctrine in the United States relating to statements and physical evidence gathered as fruits of unlawful detentions or arrests. 
the code has maintained the doctrine of 'nullities' and yet added modern statutory or even constitutional prohibitions on the use of illegally gathered evidence.

The relationship between modern rules of exclusion or 'non-usability' (inutilizzabilità, to use the Italian term), which were often inspired by the American case law of the last fifty years, and the more venerable 'nullities,' which originally related to procedural acts and not necessarily to the evidence these acts might have produced, is often difficult (at least for a lawyer schooled in the common law!) to understand. For instance, one category of nullities, called 'nullities of general order' relates to defects in the procedure which do not necessarily touch on the collection of evidence, but are treated as grave violations which can even lead to dismissal of the prosecution. ${ }^{35}$

Section 171 of CCP-France provides, 'There is a nullity when a failure to recognize a substantial formality contained in a provision of the present Code or any other provision of criminal procedure has infringed on the interests of the party to which it applies.' ${ }^{36}$ This formulation appears close to limiting France's nullity-based exclusionary rule to constitutional violations, at least when the 'party to which it applies' is the defendant. Section 174(3) further provides that the annulled act will be removed from the case dossier. In civil-law systems, the withdrawal of the document memorializing an investigative measure from the dossier traditionally meant that no use could be made of it or its contents at the trial. ${ }^{37}$ Since the document is excluded before the case reaches the trial court, the trial judge will be as insulated from the tainted evidence

35 See Codice di Procedura Penale, $\$ 178$ (entered into force 22 October 1989) [CGP-Italy]. On 'general order' nullities in France, see Richard Frase, 'France,' in Craig M Bradley, ed, Criminal Procedure: A Worldwide Study, 2d ed (Durham, NC: Carolina Academic Press, 2007) 213 [Frase].

36 Code de Procédure Pénale [CCP-France]. Código de Processo Penal \$ 563 [CCP-Brazil] also limits nullities to violations which infringe on the interests of the prosecution or the defence; $\$ 566$ to violations which affect the ascertainment of the truth or the outcome of the trial. Spain's Organic Law on the Judicial Power provides for a 'nullity' when: 'the essential rules of procedure are not respected and this may have caused an actual restriction of defense rights'; Ley Orgánica (LO) 6/1985, 1 July, Del Poder Judicial Y Del Ejercicio Potestad Jurisdiccional, $\$ 238$, online: < http://noticias. juridicas.com/base_datos/Admin/lo6-1985.html> [LOPJ-Spain].

37 In systems where the written trial still dominates, such as in the Netherlands or the French trial in the correctional courts, the documents in the dossier could historically be read at the trial. This is now changing because the European Court of Human Rights (ECtHR) has held that the use of written statements may violate ECHR, supra note 8 , art $6(3)$ (d), which guarantees the right to confrontation. See inter alia, Delta v France (1993), 16 EHRR 574 and discussion in Stephen C Thaman, Comparative Criminal Procedure: A Casebook Approach, 2d ed (Durham, NC: Carolina Academic Press, 2008) at 125-35 [Thaman, Criminal Procedure]. 
as would be a jury in the United States following a successful pre-trial motion to exclude evidence.

The CCP-Italy distinguishes between 'relative nullities,' which must be raised by the parties and if recognized may be 'sanitized' or cured by waiver by the affected party or by the official who violated the law, and 'absolute nullities,' which are usually of constitutional importance, may be raised at any stage of the proceedings, may not be 'sanitized,' and may lead to exclusion of evidence. ${ }^{39}$

Some nullity provisions also explicitly refer to derivative evidence. Thus, according to CCP-France, ' $[T]$ he 'annulled acts or documents are withdrawn from the investigative dossier' and it is 'prohibited to derive any information against the parties from the annulled acts or documents.' 10 CCP-Italy also provides that '[ $t]$ he nullity of an act renders the subsequent acts invalid which depend on that declared to be annulled. ${ }^{41}$

In Italy, the term 'nullity' usually refers to acts, whereas the term 'nonusability' refers to evidence. ${ }^{42}$ 'Non-usability' has been limited in the literature to cases where there is a statutory prohibition on the gathering of the evidence, whereas 'nullities' arise when legal formalities are violated in the gathering of what would otherwise be admissible evidence. The courts, however, have used the term 'non-usability' to apply both to both types of illegalities, creating a doctrinal murkiness. In 2001, the Italian Constitutional Court made it clear that the 'fruits of the poisonous tree' applies only to 'nullities' when expressly provided by statute, whereas CCP-Italy section 191, providing for 'non-usability' has no language referring to derivative evidence. ${ }^{43}$

CCP-Netherlands, which appears to be an adaptation of traditional nullity rules and applies to any 'procedural rule' gives the court discretion

38 CCP-Italy, supra note $35, \S \S 183-4$. For similar provisions, see Código Procesal Penal Argentino \$171 [CCP-Argentina-Federal]; Código Orgánico Processal Penal \$\$ 191 at 195 [CCP-Venezuela].

39 CCP-Italy, ibid $\$ 179$.

40 CPI-France, supra note $36, \S 174$ at para 3 . French courts have based exclusion of 'fruits' on these sections. Jean Pradel, Procédure pénale, 9th cd (Paris: Cujas, 1997) at 604-5 [Pradel].

41 Supra note $35 \S 185$ (1). For similar language, see CCP-Brazil, supra note $36, \S 573(1)$; CCP-Argentina-Federal, supra note 38, $\$ 172$; CCP-Venezuela, supra note $38 \$ 196$ at para 1.

42 CCP-Italy, supra note $35, \S 191$. See Paolo Tonini, Manuale di Procedura Penale, 6 th ed (Milan: Giuffrè Editore, 2005) at 175.

43 Italian Constitutional Court (24 September 2001), Decision No 332/2001, online: $<$ http://www.giurcost.org/decisioni/2001/0332o-01.html> [Decision No 332/2001]; c.f. Giovanni Conso \& Vittorio Grevi, Commentario Breve al Nuovo Codice di Procedura Penale, 4th ed (Padua: CEDAM, 2002) at 339 [Conso \& Grevi]. 
to exclude evidence or impose other sanctions such as barring prosecution or mitigating sentence and obligates it to 'take account of the interest that the breached rule serves, the gravity of the breach and the harm it causes.' $^{44}$

III Categorical 'pre-balanced' exclusionary rules

\section{A A GATEGORICAL EXGLUSIONARY RULE IN INTERNATIONAL LAW: THE CASE} OF TORTURE AND OF CRUEL, INHUMAN, AND DEGRADING TREATMENT Although international and regional human rights conventions firmly protect the privilege against self-incrimination ${ }^{45}$ and the right to privacy ${ }^{46}$ they do not categorically prescribe exclusion of evidence which is gathered as a direct or indirect result of the violations of these provisions. Indeed, the treaty language itself indicates that the right to privacy is not absolute. It may be violated, according to ECHR article $8(2)$, 'in accordance with the law' and when 'necessary in a democratic society in the interests of national security, public safety or the economic well-being of the country, for the prevention of disorder or crime, for the protection of health or morals, or for the protection of the rights or freedoms of others. ${ }^{47}$

The prohibition against torture or other cruel, inhuman, and degrading treatment, however, is treated as absolute. There is no qualifying language in the treaty texts, ${ }^{48}$ and states may not derogate from this protection, even in times of war or public emergency. ${ }^{49}$ Although the human rights treaties do not have built-in exclusionary rules, of the Convention against Torture and Other Cruel, Inhuman or Degrading Treatment (CAT) to which 146 nations are a party, ${ }^{50}$ clearly prohibits the use of statements gathered through torture. But, oddly enough, the CAT does not provide an explicit exclusionary rule for statements gathered through

44 Wetboek van Strafuordering $\$ 359$ a [CCP-Netherlands].

45 ICCP, supra note 9 , art $14(3)(\mathrm{g})$; ACHR, supra note 10 , art $8(2)(\mathrm{g})$. The ECIR recognized the right to silence as being part of the right to a fair trial guaranteed under art 6(1); see ECHR John Murray $v$ The United Kingdom, [1996] 3, (1996), 22 EHRR 29 at 60.

46 UDHR, supra note 7, art 12; ICCP, ibid, art 17(1); ECHR, supra note 8, art 8(1); ACHR, supra note 10 , art $11(2)$.

47 ECHR, ibid, art 8(2). UDHR, ibid, art 12 prohibits 'arbitrary' interference; ICCP, ibid, art 17(1) prohibits 'arbitrary and unlawful' interference; and ACHR, ibid, art 11(2), prohibits 'arbitrary and abusive' interference.

48 UDHR, ibid, art 5; ICCP, ibid, art 7; ECHR, supra note 8, art 3; ACHR, ibid, art 5(2). 49 ICCP, ibid, art 4(2); ECHR, supra note 8, art 15(3).

50 Convention against Torture and Other Cruel, Inhumane or Degrading Treatment or Punishment, GA Res 39/46, UNGAOR, 39th Sess, Supp No 51, UN Doc A/39/51 (1984) § 15, online: $<$ http://treaties.un.org/Pages/ViewDetails.aspx?src=UNTSONLINE\&tabid=2\&:mtdsg_no= IV-9\&chapter $=4 \&$ \&lang=en\#Participants $>$. 
use of 'cruel, inhuman or degrading treatment." The UN's 'Body of Principles for the Protection of All Persons under Any Form of Detention or Imprisonment,' however, requires prosecutors to refuse to use as evidence statements obtained by torture "or other ill treatment except in proceedings against those who are accused of using such means.'52 The Grand Chamber of the European Court of Human Rights (ECtHR) also clearly held in the case of Gäfgen $v$ Germany that the use of any statements gathered through torture or inhuman or degrading treatment would result in an unfair trial in violation of ECHR article $6 .^{53}$

Although CAT does not mention exclusion of the 'fruits of the poisonous tree' derived from confessions under torture, it is presumed that the use of physical or other evidence derived from torture would also violate the treaty and international law. The ECtHR held in Gäfgen that use of fruits of a tortured confession would automatically result in the violation of the right to a fair trial, though it admitted that its case law was not as categorical when it came to the fruits of 'inhuman or degrading' treatment, also prohibited categorically by ECHR article $3 .^{54}$

In Gäfgen, police threatened a Frankfurt law student with torture and brutality if he did not reveal the whereabouts of a child kidnap victim, who they thought was still alive. He made incriminating statements and took them to the lake where he had disposed of the child's body. A report of the autopsy conducted on the boy's body and evidence of the tire tracks of defendant's car ncar the lake were used at trial, though all his statements were suppressed. ${ }^{55}$ The ECHR Grand Chamber deemed that the threats constituted 'inhuman and degrading' treatment and were thus in violation of ECHR article 3 but did not rise to torture. It also found that, in such a case, the use of the fruits would not violate the ECHR right to a fair trial, ${ }^{, 6}$ using a kind of 'harmless error' analysis. Since

51 Michael P Scharf, 'Tainted Provenance: When, If Ever, Should Torture Evidence Be Admissible?’ (2008) 65 Wash \& Lee L Rev 129 at 140.

52 Ibid at 145.

53 Gäfgen v Germany (2011), 52 EHRR 1 at 42, para 166 [Gäfgen]. It appears here that the ECtHR is treating the use of statements at trial, which were obtained as a result of the violation of ECHR, supra note 8, art 3, as absolute reversible error, not subject to any 'harmless error' analysis. US Courts would likely apply the doctrine of 'harmless constitutional error' to such a situation, for so-called 'structural errors,' which constitute automatic reversible errors, are usually not related to the erroneous admission of cvidence, and thus are much like 'nullities of general order' in civil-law systems; see note 37 supra and accompanying text. On structural and harmless constitutional error in the United States, see Wayne $\mathrm{R}$ LaFave et al, Criminal Procedure, 5th ed (St. Paul: West, 2009) at 1323-31 [LaFave et al].

54 Gäfgen, supra note 53 at 42 , paras $166-7$.

55 Ibid at $6-7 ; 9-10$, paras $15-8 ; 29-31$.

56 ECHR, supra note 8 , art 6. 
the defendant confessed his guilt at trial, the court found that his courtroom testimony was no longer the fruit of the article 3 violation since he was represented by counsel, and the court based its guilty judgment on the courtroom confession alone, only using the 'ill-gotten fruits' to corroborate its truthfulness. ${ }^{57}$

Despite the fact that the ECtHR in Gäfgen recognized certain exceptions to an absolute exclusionary rule for fruits of inhuman and degrading interrogation practices not amounting to torture, such as 'harmless error,' 'inevitable discovery, ${ }^{38}$ and attenuation of the taint of the illegality, it also expressly disallows any 'balancing' of this 'absolute' violation against other interests, such as the 'the seriousness of the offence under investigation or the public interest in effective criminal prosecution, ${ }^{59}$ which are at the core of Germany's balancing test, which will be discussed below.

Long before the adoption of the CAT, national legal systems provided for categorical exclusion of statements obtained by threats, force, deception, promises, or other means, such as to render them 'involuntary,' which might fall short of cruel, inhuman, and dcgrading treatment or torture. Thus, CCP-Germany ${ }^{60}$ prohibits the use of 'maltreatment, fatigue, physical intervention, the administration of substances, torture, deception, hypnosis, threats to apply measures not applicable according to the rules, or promises of a benefit not provided by law' during questioning and provides for a mandatory exclusionary rule if the prohibitions are violated. ${ }^{61}$

In 1897, the USSC held that, for statements taken in police custodial interrogation to be admissible under the Fifth Amendment privilege against self-incrimination, they must 'not be extracted by any sort of threats or violence, nor obtained by any direct or implied promises, however slight, nor by the exertion of any improper influence.' ${ }^{62}$ Between 1936 to 1966, the USSC also condemned interrogation practices ranging from clear torture to lesser modes of coercion, threats, promises, deception, and so forth which might or might not today rise to the level of cruel, inhuman, or degrading treatment, as violations of 'due process' and required reversals of thirty-five convictions based thereon. ${ }^{68} \mathrm{I}$ will discuss exclusionary rules dealing with 'involuntary' confessions which were induced by practices which do not rise to the level of torture or cruel, inhuman and degrading treatment, below.

57 Gäfgen, supra note 53 at 44-6, paras 177-83.

58 Ibid at 44, para 174.

59 Ibid at para $175-6$.

60 Strafprozessordnung $\$ 136$ a [CCP-Germany].

61 Similar rules are common in other modern codes of criminal procedure as well; c.f. CPP-Italy, supra note $35 \$ 64(3)$ and Ugolownoprotsessual'nyy kodeks Rossiyskoy Federatsii (2001) § 9 [CCP-Russia].

62 Bram v United States, 168 US 532 at 542 (1897).

63 For a summary of these 'voluntariness' cases, see LaFave et al, supra note 53 at 343-9. 
B CATEGORICAL GENERAL EXGLUSIONARY RULES APPLYING TO VIOLATIONS OF CONSTITUTIONAL AND SUB-CONSTITUTIONAL STATUTORY LAW

A number of constitutions adopted by democratizing countries emerging from the clutches of totalitarian, authoritarian, or dictatorial regimes specifically require the exclusion of illegally gathered evidence. This is an important step, because some courts that require suppression of evidence following a constitutional violation do not acknowledge that the exclusionary rule itself is of constitutional stature. ${ }^{64}$

Some of these exclusionary provisions apply to evidence gathered in violation of statutory provisions which do not rise to violations of fundamental or constitutional rights. For instance, the 1993 Russian Constitution ${ }^{65}$ provides, 'In the administration of justice the use of evidence gathered in violation of federal law is not permitted. ' ${ }^{66}$ Similarly, article 5(LVI) of the Brazilian Constitution ${ }^{67}$ provides for inadmissibility of evidence obtained by 'illegal means. ${ }^{\prime}{ }^{6}$ Here, the constitutional legislator has already balanced, or to put it another way, has pre-empted all balancing by law givers or lowercourt judges. In Russia, the extension of the provisions to errors of non-constitutional gravity has been criticized. ${ }^{69}$

There are equally broad-sounding exclusionary rules in some of the new codes of criminal procedure. CCP-Italy (1988) provides for a sanction of 'non-usability' in relation to 'evidence acquired in violation of prohibitions established by the law.' ${ }^{\prime 70}$ CCP-Serbia (2006) goes even further:

64 I am, of course, referring to the convoluted attempts by the USSC to characterize Mapp's, supra note 18, Fourth Amendment exclusionary rule and Miranda's, supra note 22, Fifth Amendment exclusionary rule (Miranda rule) as 'prophylactic' rules not required by the constitutional amendments they were originally designed to safeguard. See Leon, supra note 26 at 897, in relation to the Fourth Amendment exclusionary rule and, most recently, United States v Patane, 542 US 630 at 631 (2004) [Patane], in relation to the Miranda rule.

65 Konstitutsia Rossiyskoy Federatsii art 50(2) [Const. Russia].

66 For similar language, see Constitution of the Republic of Georgia (1995) art 42(7) [ConstGeorgia]; Constitution of the Republic of Azerbaijan (1995) art 71(3) [Const-Azerbaijan]; Constitution of the Republic of Belarus art 27(2); Constitution of the Republic of Kazakhstan (1995) art 77(3) (9) [Const-Kazakhstan]. CCP-Russia, supra note $61, \S 75$ (1), includes the same broad exclusionary mandate, as does Ugolowno-protsessual'nyy Kodeks Respubliki Belarus \& 105(4)-(5) [CCP-Belarus]; Ugolowno-protsessual'nyy Zakon Respublika kazakhstan \$ 116(4) [CCP-Kazakhstan]; Ugolownoprotsessual'nyy Kodeks Kyrgyzskoy Respubliki $\&$ 6(3) [CCP-Kyrgyzstan]; Ugolouno-protsessual'nyy kodeks Turkmenistana \$ 125(4) [CCP-Turkmenistan].

67 Constitution of Brazil (1988) [Const-Brazil].

68 C.f. Constitution of the Republic of Turkey (1982) $\$ 38$ at para 8 [Const-Turkey] and Turkish Criminal Procedure Code $\$ 206$ (a) (2) [CCP-Turkey], which use similar language.

69 See Stephen C Thaman, 'The Resurrection of Trial by Jury in Russia' (1995) 31 Stan J Int'l $L$ 61 at 90-4, discussing exclusionary practices and criticism of the broad rule in jury trials in 1993-4.

70 CCP-Italy, supra note $35, \S 191$. 
Court decisions may not be based on evidence which per se, or by method of collection is contrary to the provisions of the present Code, any other law, or has been collected or presented by virtue of violating human rights and fundamental freedoms envisaged by the Constitution or ratified international treaties. ${ }^{1}$

Occasionally these broad exclusionary rules will even extend to derivative evidence; that is, to 'fruits of the poisonous tree.' Thus, $\$ 83 \mathrm{CCP}-$ Slovenia (1994) provides that a court may not base a decision on evidence acquired in violation of constitutional rights and liberties, nor of other explicit norms of criminal procedure, nor on evidence derived from such violations. ${ }^{72}$

These broad rules seem to hearken back to equally broad 'nullity' provisions which are rooted in a strict legality principle according to which any law violation nullifies the validity of the acts which are the results thereof. We will see, however, that the blind eye exercised by courts in relation to the admissibility of otherwise relevant evidence seized in violation of statutory 'nullities' in traditional civil-law regimes also lacks acuity when it comes to interpreting modern exclusionary rules. ${ }^{73}$

\section{CATEGORICAL GENERAL EXCLUSIONARY RULES RESTRICTED TO}

VIOLATIONS OF FUNDAMENTAL OR CONSTITUTIONAL RIGHTS

I believe the better approach is to limit categorical exclusionary rules to situations where fundamental or constitutional rights are violated. ${ }^{74} \mathrm{~A}$ statute which I believe could be a model for other jurisdictions and that expressly extends to the 'fruits of the poisonous tree' is LOPJSpain, which provides, 'Evidence obtained, directly or indirectly in violation of fundamental rights and liberties is without effect. ${ }^{75}$ In a similar manner, CCP-Colombia provides for exclusion of '[a]ll evidence obtained in violation of fundamental guarantees' and extends the prohibition to '[e] vidence which is the consequence of the excluded evidence, or can only be explained by reason of its existence.' ${ }^{76}$

71 Criminal Procedure Code $\$ 15$ [CCP-Serbia]. For a US statutory exclusionary rule extending to non-constitutional statutory violations, see Vernon's Ann Texas CCP art 38.23 .

72 Criminal Procedure Act (2007) [CCP-Slovenia] \& 83 [CCP-Slovenia]; see Zvonka Fišer et al, La legislazione processuale penale della Repubblica di Slovenia, in Berislav Pavišić \& Davide Bertaccini, eds, Le altre procedure penali: Transizioni dei sistemi processuali penali, vol 1 (Turin, Italy: G Giappichelli, 2002).

73 The interpretation of CCP-Italy, supra note $35, \S 191$, is a good case in point. See Part E.ii.b.2 below.

74 C.f. 4 Or Rev Stat $\$ 136.4320$, which limits exclusion of evidence to situations when required by the constitutions of Oregon or the United States.

75 Supra note $36, \$ 11.1$.

76 Códigos de Procedimiento Penal $\$ 23$ [CCP-Colombia]. 
Derivative evidence, however, is only a 'fruit' of the violation if there is a close causal connection between the violation and its discovery and the evidence would not have been discovered but for the violation. Some recent statutes explicitly provide for exceptions to exclusion developed in US jurisprudence. For instance, CCP-Brazil (2008) provides,

Illicit evidence, understood to be that obtained in violation of constitutional and legal norms, is inadmissible and should be removed from the trial: (1) the evidence derived from the illicit evidence is also inadmissible except where there is no obvious or causal nexus between the one and the other or where the derived evidence could be obtained from a source independent of the former; (2) An independent source is considered to be such, that when, following the normal procedures used in practice which are proper in criminal investigation, it would be capable of leading to the facts which are the objects to be proved $^{77}$

In a similar vein, CCP-Colombia explicitly makes exceptions for 'attenuated connection, independent source, inevitable discovery, and others provided by law.' ${ }^{38}$

IV What is a constitutional or fundamental right?

\section{A INTRODUCTION}

Assuming that most jurisdictions will only exclude probative evidence if the police violate a fundamental or constitutional right, it is still not always easy for courts or law givers to determine which violations fall into this category. Courts thus make value judgments which could be considered to be a balancing of the seriousness of the violation in relation to the legal interest protected by a constitutional provision. The Constitution of Colombia states that 'evidence obtained in violation of due process is null in the full sense of the law (in pleno derecho)..$^{79} \mathrm{We}$ know from USSC case law that determining what is a violation of due process in the taking of a confession or 'probable cause' in the issuance of a warrant to search or wiretap can imply a complicated weighing of the 'totality of the circumstances.' ${ }^{80}$ The Constitution of Portugal lists specific constitutional violations which will trigger exclusion: "Any evidence

77 Supra note $36, \$ 157$.

78 Supra note $76, \S 455$.

79 Constitution of Calumbia (1991) art 29 [Const-Columbia].

80 On the 'totality of the circumstances' approach related to the admissibility of arguably 'involuntary confessions,' see LaFave et al, supra note 53 at 343-9. In relation to determining 'probable cause,' see Illinois $v$ Gates, 462 US 213 at 267-74 (1983) [Gates]. 
obtained by torture, force, violation of the physical or moral integrity of the individual, wrongful interference in private life, the home, correspondence, or telecommunications is of no effect. ${ }^{\text {si }}$

We have already seen that the nullities approach adopted in many civillaw criminal procedure codes differentiates between nullities which affect constitutional rights or substantial interests of the defendant, called 'absolute' nullities or nullities of 'general order,' and those which are only relative and may be sanitized, and so on. The German Supreme Court, in a similar way, has found that '[i]f the procedural provision which has been violated, does not, or not primarily, serve to protect the defendant, then a prohibition on use will be unlikely; on the other hand, a prohibition on use is appropriate, when the violated procedural provision is designed to secure the foundations of the procedural position of the accused or defendant in a criminal prosecution. ${ }^{82}$

The right to privacy in one's home and one's communications and the right to remain silent are core constitutional rights in all democracies, but it is also legal for police to search homes, intercept private communications, and interrogate criminal suspects if they follow the correct procedures. Some of the procedures are directly required by constitutions or constitutional decisions of high courts because they affect the core interests protected by the constitutional rights if violated. Other rules dictated by statute are often considered to be of lesser importance. I will assess what I believe to be the core rules in these two areas which should usually trigger exclusion of evidence if violated.

\section{B THE CONSTITUTIONALITY OF LIMITATIONS ON GOVERNMENTAL} INVASIONS OF PRIVACY

\section{i The requirement of probable cause and judicial authorization}

If a dwelling search or wiretap is based on probable cause and is judicially authorized, its constitutional underpinnings are normally guaranteed. I believe that these are the two core factors which, to use the language of the ECHR, are 'necessary in a democratic society'ss before authorities invade protected areas of privacy for the purposes of criminal investigation. If the investigative measure violates statutory rules which are unrelated to the amount of suspicion necessary to search or wiretap or to the fact of judicial authorization, then the Spanish courts, for instance, consider the violation to be an 'irregularity' rather than an 'illegality' and treat it like a 'relative

81 Constitution of the Portuguese Republic, 7th revision (2005) art 32(6) [Const-Portugal] required.

8238 BGHSt 214 at 218-22; for English translation, see Thaman, Criminal Procedure, supra note 37 at 111 [ 38 BGHSt 214].

83 Supra note 8 , art 8 . 
nullity' which would not lead to exclusion of evidence.$^{84}$ For example, in one Spanish case, the police conducted a search which was authorized by the investigating magistrate and based on sufficient suspicion, but neither the investigating magistrate nor his secretary were present during the search, violating a statutory norm regulating the execution of searches. The Spanish Supreme Court held that this error did not affect a fundamental right, and therefore the sanction was merely the annulment of the act documenting the search, making it inadmissible at trial. This, however, did not prevent the police who conducted the search from testifying in court to prove the seizure of the drugs and the corpus delicti of the crime ${ }^{85}$

In principle, the USSC has also categorized certain violations of the laws regulating wiretaps and search warrants as being of sub-constitutional status so that violation does not require suppression. Thus, mistakes in the execution of an otherwise valid search warrant ${ }^{86}$ or wiretap ${ }^{87}$ will not lead to exclusion. By refusing to suppress the fruits of an otherwise constitutionally valid warranted search in Hudson $v$ Michigan ${ }^{88}$ despite a violation of the 'knock and announce' requirement of Federal Rules of Criminal Procedure 41 , the USSC has come to a result similar to that of the Spanish Supreme Court but had to resort to contorted reasoning because of a previous decision in which complying with the 'knock and announce' rule was declared to be constitutionally required ${ }^{89}$

There will, of course, be differences in the interpretation of what is an unconstitutional search because, while the United States requires 'probable cause' for the issuance of a search warrant or wiretap, ${ }^{90}$ some other countries, such as Germany, Spain, or France, appear to require a lesser degree of suspicion."1

84 On the notion that 'illicit evidence' is suppressible under LOPJ-Spain, supra note $36, \S$ 11.1 and that 'irregular' evidence falls under LOPJ-Spain, ibid \$ 238, the nullity provision, and does not lead to suppression of fruits of the violation, see Marien Aguilera Morales, 'Regla de exclusión y acusatorio' in Lorena Bachmaier Winter et al, Proceso penal y sistemas acusatorios (Madrid: Marcial Pons, 2008) 93 [Morales].

85 Supreme Court of Spain, Decision of July 9, 1993, RJ 1993, No 6060, 7682 at 7682-3; for English translation, see Thaman, Criminal Procedure, supra note 37 at 106-8.

86 See the following two cases in which aspects of Federal Rules of Criminal Procedure 41 regulating serving of search warrants were violated: United States $v$ Schoenheit, $856 \mathrm{~F}$ (2d) 74 (8th Cir 1988), on violation of prohibition of night service; United States v Charles, $883 \mathrm{~F}$ (2d) 355 (5th Cir 1989), on serving officer did not have warrant in hand.

87 In relation to the wiretap statute, the provision must 'directly and substantially implement' the congressional intention to restrict the use of electronic surveillance or be 'intended to play a central role in the statutory scheme.' United States v Giordano, 416 US 505 at 527 (1974); United States v Chavez, 416 US 562 at 574 (1974).

88 Supra note 33 at 594 .

89 See Wilson v Arkansas, 514 US 927 (1995). The Court had to base its decision on the fact that the seizure of the evidence was not a 'fruit' of the unlawful entry; see also Hudson, ibid at 586-7.

90 Described as a 'fair probability' that the thing searched for will be present in the indicated location; Gates, supra note 80 at 238. 


\section{ii The constitutional exception for exigent circumstances}

Both the German and Italian Constitutions provide for an exception to the warrant requirement in cases of exigent circumstances, or what the Germans call 'danger in delay. ${ }^{{ }^{2} 2}$ This exception is universally recognized but can easily be abused, so it is important that it be narrowly construed to prevent large-scale evasion of the requirement of pre-search or prewiretap judicial authorization.

Although it was well-known that German law enforcement officials seldom, if ever, acquired search warrants ${ }^{93}$ and always (successfully) defended their warrantless searches retrospectively ${ }^{94}$ with a perfunctory incantation of the words 'danger in delay,' often attributed to the fact that there were no evening-duty judges to issue warrants, the appellate courts winked at this sleight of hand, claiming the trial judge's discretion could not be reviewed on appeal. ${ }^{95}$ The German Constitutional Court finally took note of this scandalous situation in 2001 and attempted to rectify the situation by limiting the exception for 'danger in delay' to cases that were clearly documented and by requiring judges to be on duty twenty-four hours for the purposes of issuing warrants. ${ }^{96}$

To prevent such manipulation, the exception for 'exigent circumstances' should be limited to two fact situations: the 'flagrant crime' ${ }^{\text {97 }}$ and real emergency situations involving threat to human life, health, or property. An example of a statute that puts clear restrictions on the invocation of 'exigent circumstances' is the US federal wiretap statute, which allows warrantless wiretaps only in emergency situations that involve

91 On the ncar complete discretion of French judges to search any place and seize anything that the judge deems 'useful to the manifestation of the truth,' see Frase, supra note 35 at 211. On the low substantive barriers to searches in Germany, where mere 'suspicion' is sufficient, see Thomas Weigend, 'Germany' in Craig M Bradley, cd, Criminal Pracedure: A Worldwide Siudy, 2d ed (Durham, NC: Carolina Academic Press, 2007) 243 at 249 [Weigend]. For a Spanish investigating magistrate to order a search, there need only be 'indications' that the person or objects sought are located therein; Ley de Enjuiciamiento Criminal \$ 546 [CCP-Spain].

92 The exception for 'exigent circunstances' is found in Basic Law for the Federal Republic of Germany art 13(2) [Const-Germany] and Constitution of the Italian Republic art 14 [Const-Italy].

93 Weigend, supra note 91 at 250 estimated that only $10 \%$ of searches were conducted with warrants.

94 In Germany and many other countries, police must acquire judicial validation of exigent searches within two or three days after the scarch; see CCP-Germany, supra note $60, \$ 98(2)$.

95 Andreas Ransiek, 'Durchsuchung, Beschlagnahme und Verwertungsverbot' (2002) 10 Der Strafverteidiger 565 at 566 [Ransick]. In effect, only the most arbitrary searches ever led to exclusion of evidence; ibid.

96 BVerfGE 103 at 142.

97 An exception specifically included in Constitución Española de 27 diciembre 1978 art 18(2) [Const-Spain]. 
'immediate danger of death or serious physical injury to any person' or for conspiratorial activities that threaten 'the national security interest' or are "characteristic of organized crime. ${ }^{\text {"98 }}$ The USSC has also created an exception to the warrant requirement which allows police to enter a house with less than probable cause to save lives, prevent injuries, or protect property. ${ }^{99}$

The 'flagrant crime' exception would apply to 'hot pursuit' cases, ${ }^{100}$ where probable cause develops suddenly upon commission of a crime and escapc of the culprit or destruction of evidence is likely. If, however, the suspicion of the presence of drugs in a dwelling, for instance, comes as a result of an investigation, then, in principle, a warrant should be obtained. The police should not be able to create the need for exigent circumstances by, for instance, walking up to the target house and announcing they are present so as to create a pretext for entering to prevent the destruction of evidence. ${ }^{101}$

\section{iii Instances where a constitutional violation permits of no further balancing}

Thus, when a home has been searched without a search warrant bascd on probable cause or without exigent circumstances, this should be considered to be a clear constitutional violation and exclusion should be the presumptive remedy. This was traditionally the approach of the USSC following Mapp ${ }^{102}$ until the 'good faith' test and 'cost-benefit' balancing was introduced in Leon, ${ }^{103}$ as it was for the Spanish courts in interpreting LOPJ-Spain section $11.1^{104}$ until balancing was introduced in 1998, as long as the taint of the violation was not attenuated. The Irish Supreme Court, which initially employed a simple balancing test to determine admissibility of evidence, ${ }^{105}$ changed course in 1990 and recognized a categorical exclusionary rule in cases where police clearly violate the constitutional rights of citizens, rejecting even the 'good faith' exception recognized by the USSC. According to Judge Finlay in People (DPP) $v$ Kenny, 'The detection of crime and the conviction of guilty persons, no

9818 USC $\$ 2518$ (7) (a). The federal prosecutor must then request post factum approval of a judge within forty-eight hours. Such immediate review after an emergency invasion of privacy is otherwise not required for emergency searches in the United States.

99 Brigham City, Utah o Stuart, 547 US 398 at 403 (2006). Such searches should not, however, be pretexts for searches for evidence of crime.

100 See Warden v Hayden, 387 US 294 at 310 (1967) [Warden].

101 See United States $v$ Timberlake, 896 F (2d) 592 at 597 (DC Cir 1990); Dunnuck $v$ State, 786 A (2d) 695 at 699-700 (Md 2001) with respect to knocking on a door without warrant. But see contra United States v MacDonald, 916 F (2d) 766 at 772 (2d Cir 1990), allowing creation of exigent circumstances by knocking on the door.

102 Supra note 18.

103 Supra note 26.

104 See text accompanying note 75 supra.

105 See People (AG) y O'Brien, [1965] IR 142 at 160-1 SG (I). 
matter how important they may be in relation to the ordering of society, cannot, however, in my view, outweigh the unambiguously expressed constitutional obligation as far as practicable to defend and vindicate the personal rights of the citizen. ${ }^{106}$

Categorical statutory exclusionary rules are otherwise clcarly less common in relation to violations of the right to privacy than they are for violations of the right to counsel or silence in the context of interrogations. The great exception, however, is with violations of the wiretap statutes. Thus, when core provisions of the US wiretap statute have been violated, the federal code provides that

no part of the contents of such communication and no evidence derived therefrom may be received in evidence in any trial, hearing, or other procecding in or before any court, grand jury, department, officer, agency, regulatory body, legislative committee, or other authority of the United States, a State, or a political subdivision thereof. ${ }^{107}$

This is likely the broadest explicit statutory exclusionary rule in US law and clearly extends to 'fruits of the poisonous tree.' It also brooks of no exceptions based in 'standing' or 'good faith' mistakes. ${ }^{108}$ CCP-Italy also expressly prohibits use of the 'results of interceptions' made in violation of the wiretap statute. ${ }^{109}$

A key reason for court reluctance to exclude evidence gained from violations of the right to privacy has been that such violations usually occur unrelated to the violation of any trial right such as the privilege against self-incrimination and thus, in the words of the German Supreme Court, will not affect the 'procedural position' of the defendant, or in the approach of the ECtHR, will not affect the right to a fair trial protected by ECHR article 6. ${ }^{110}$

\section{CONSTITUTIONAL LIMITATIONS ON INTERROGATION PRACTICES}

\section{$\mathrm{i}$ Admonitions as to the right to silence and to counsel}

While the use of means such as torture; cruel, inhuman, and degrading treatment; and lesser tactics which render a confession 'involuntary' clearly constitute a fundamental rights violation that leads to suppression

106 [1990] 2 IR 110 at 134 SC (I) (Finlay CJ).

10718 USC $\$ 2515$.

108 See United States $v$ Rice, 478 F (3d) 704 at 711-2 (6th Cir 2007), which finds there is no 'good faith' exception to the wiretap exclusionary rule.

109 Supra note $35, \$ 271$.

110 In Leon, supra note 26 at 906 , the USSC stated that the wrong perpetrated by the Fourth Amendment violation is 'fully accomplished' at the time of the illegal search and no 'new Fourth Amendment wrong' is perpetrated by admitting illegally scized evidence into the trial. The 'fair trial' test of the ECtHR will be discussed in Part IV-B below. 
of an ensuing statement, another very important procedural rule is the requirement that a suspect or defendant be aware of the right to silence and the right to counsel before being questioned. ${ }^{111}$ Whereas the former, more egregious violation constitutes an attack on human dignity and sometimes bodily integrity, the latter is more of a procedural error which undermines the defendant's ability to defend herself during the criminal trial.

The warnings made famous in the USSC's landmark decision of Miranda $v$ Arizona ${ }^{112}$ were deemed by the majority in that case to be firmly rooted in the Fifth Amendment and therefore constitutionally required to dissipate the inherent coerciveness of custodial interrogation. The consequence of a violation of the rules the Court laid down was exclusion of the statements gathered following the violation. The USSC also claimed that it is with custodial interrogation that 'our adversary system of criminal proceedings commences.'113 In a similar vein, the German Supreme Court has proclaimed that the German variant of Miranda warnings are 'designed to secure the foundations of the procedural position of the accused.' Exclusion of a statement taken in violation of the German Miranda-warnings is mandated even if the suspect interrogated was out of custody, as long as probable cause existed to arrest him for the crime which was the subject of the interrogation. ${ }^{114}$

Although most democratic countries have adopted the teaching of Miranda, the constitutional underpinnings of the rule have been called into question in the country of their origin. In 1971, the USSC began permitting the use of a statement taken in violation of the Miranda rules in order to impeach a defendant whose courtroom testimony contradicted it. ${ }^{115}$ By 1974, the violation of the Miranda rules was no longer characterized as a violation of the Fifth Amendment privilege against self-incrimination or the Sixth Amendment right to counsel but as a 'prophylactic rule' the violation of which would not affect the use of the 'fruits of the poisonous tree. ${ }^{116}$ Although the USSC reversed course in 2000 and declared that the Miranda warnings were of constitutional status, ${ }^{117}$ it refused to reverse the exceptions to the exclusionary rule based in its

111 Most European and Latin American jurisdictions now require that persons subject to police interrogation be admonished of their right to confer with counsel and their right to remain silent before being interrogated; see Thaman, Criminal Procedure, supra note 37 at $85-96$. In general, see Stephen $C$ Thaman, 'Miranda in Comparative Perspective' (2001) 45 Saint Louis ULJ 581.

112 Supra note 22.

113 Ibid at 477.

11438 BGHSt 214 , supra note 82 at $218-22,224-5$.

115 Harris $y$ New York, 401 US 222 at 225-6 (1971).

116 Michigan $v$ Tucker, 417 US 433 at 438-9, 450 (1974).

117 Dickersm v United States, 530 US 428 at 437-8 (2000). 
sub-constitutional status and a plurality of the Court recently returned to calling Miranda warnings mere 'prophylactic' safeguards not themselves required by the Fifth Amendment in holding that physical evidence found as a result of a Miranda-defective confession is admissible. ${ }^{118}$

\section{ii The actual right to counsel before and during interrogations}

Although the Miranda decision clearly intimated that an uncharged suspect in custody must be advised of the right to have counsel present during the entire interrogation, ${ }^{119}$ the Court never required that police assure that those facing interrogation are actually able to speak to lawyers before deciding whether they will waive their rights. ${ }^{20}$ Police can even tell suspects that no lawyer will be provided until they are charged and go to court ${ }^{121}$ or refuse to tell a suspect that a lawyer has been actually retained. ${ }^{122}$ An invocation of the right to counsel will certainly prevent any further interrogation of a jailed uncharged suspect even as to different charges unless the defendant reinitiates contact with the interrogators, ${ }^{123}$ but the dissent of Justice White in Mirand a already expressed doubt as to whether a waiver of the right to counsel allowed by the majority could ever truly considered to be voluntary if custody was per se coercive in the first place. ${ }^{124}$

As a result, the overwhelming majority of suspects in the United States waive their Miranda rights and speak to police without ever having talked to a lawyer ${ }^{125}$ Although the USSC originally held that once a person is charged and is represented by counsel or has requested or been assigned counsel, no interrogation may take place in the absence of counsel or without counsel's consent. But that rule was recently overruled by the USSC, and the Miranda rules now apply whether or not the suspect is represented by counsel. ${ }^{126}$

118 Patane, supra note 64 at 632.

119 Supra note 22 at 492 . This was clearly reaffirmed in Florida v Powell, 130 S Ct 1195 at $1211(2010)$.

120 The Miranda court, supra note 22 at 474, said it was not necessary to have a system of 'station house lawyers' ready to advise incarcerated suspects as is required in England and Wales under the system of 'duty solicitors'; see England and Walcs, Code of Practice (C) at para 6.6(a)-(c) [PACE].

121 California v Prysock, 453 US 355 (1981); Duckworth v Eagan, 442 US 195 (1989).

122 Moran v Burbine, 475 US 412 at 422 (1986). The Court stated, 'No doubt the additional information would have been useful to respondent; perhaps it even might have affected his decision to confess.'

123 Edwards v Arizona, 451 US 477 (1981) [Edwards]; Arizona v Roberson, 486 US 675 (1988).

124 Supra note 22 at $536-7$ (White, dissenting).

125 According to one study, only around one quarter of suspects elected to remain silent. Richard Leo, 'The Impact of Miranda Revisited' (1996) 86 J Crim L \& Criminology 621 at 657-9.

126 Montejo v Louisiana, 129 S Ct 2079 at 2085, 2089-91 (2009). 
Unlike in the United States, however, in Europe the right actually to consult with counsel before and during interrogation is obtaining indubitable constitutional status as a fundamental right. According to CCPRussia, for example, no pre-trial statement made by a defendant to law enforcement officials which was given in the absence of counsel may be used at trial if the defendant retracts the statement at or before trial even if the suspect waived the right to counsel. ${ }^{127} \mathrm{~A}$ similar rule has been recognized in Spain. ${ }^{128}$ In Italy, the denial of the assistance of counsel constitutes a nullity of general order and, in the context of police interrogation, an 'absolute nullity' which cannot be sanitized and must be raised ex officio by the judge. ${ }^{129}$ Exclusion follows even if the suspect offers a statement voluntarily in the absence of counsel..$^{130}$

Traditionally, some European regimes gave the police a determinate period to interrogate suspects (called garde $a$ vue in France and Belgium) and the right to counsel was only recognized for subsequent interrogation by an investigating magistrate. ${ }^{131}$ In 2008, however, the Grand Chamber of the ECtHR in Salduz $v$ Turkey ${ }^{132}$ held that the right to counsel, guaranteed by ECHR article 6(3) (c) applics not only at trial but also during the investigative stage and most assuredly during the first police interrogation. Any conviction based on an admission or statement taken in violation of this right constitutes a violation of the general right to a fair trial guaranteed under ECHR article 6(1).

127 CCP-Russia, supra note $61, \S 75(2)(1)$. This provision was introduced due to the prevalent use of coercion by Russian criminal investigators, not only in inducing confessions, but also in inducing waivers of counsel prior to interrogation. Cf Stephen C Thaman, 'The Nullification of the Russian Jury: Lessons for Jury-Inspired Reform in Eurasia and Beyond' (2007) 40 Cornell Int'l LJ 355 at 375-8.

128 See CCP-Spain, supra note $91, \S \S 520(2)(a)-(c)$ and discussion in Eduardo de Urbano Castrillo \& Miguel Ángel Torres Morato, La Pmueba Mlícita Penal: Estudio jurispmudencial, 3d ed (Navarra, Spain: Thomson; Aranzadi, 2003) at 78 [Urbano Castrillo \&c Torres Morato].

129 CCP-Italy, supra note $35, \$ \$ 178(1)(c), 179(1), 350(3)$, and discussion in Marilena Colamussi, 'In tema di deducibilitá della nullitá derivante dalla violazione del diritto dell'imputato in stato di custodia cautelare di conferire con il proprio difensore' in Vincenzo Perchinunno, ed, Percorsi di Procedura Penale. Dal garantismo inquisitorio a un accusatorio non garantito (Milan: Giuffrè, 1996) at 37.

130 CCP-Italy, ibid $\$ 350(6,7)$.

131 On how much easier it was for police to get confessions in the absence of counsel than during questioning by the juge d"instruction, see Pradel, supra note 40 at $386-97$. Today, the suspect in police custody is not advised of the right to counsel but may request to see counsel during garde à vue, but the interview may not exceed thirty minutes and the lawyer has no right to be present during police interrogation. CCP-France, supra note $36, \$ \$ 63-4$. In Belgium, there was no right to counsel even during interrogation before the investigating magistrate; see Laurens van Puyenbroeck, 'Belgium' in Ed Cape et al, eds, Effective Criminal Defence in Europe (Oxford, UK: Intersentia, 2010) 78.

132 (2009), 49 EHRR 421 [Salduz]. 
The Court said, 'The rights of the defence will in principle be irretrievably prejudiced when incriminating statements made during police interrogation without access to a lawyer are used for a conviction.' ${ }^{193}$ The Grand Chamber did, however, allow for waivers of fair trial rights $^{194}$ and this could be interpreted as allowing the right to waive the right to counsel during the first interrogation. ${ }^{135}$

The decisions subsequent to Salduz, however, indicate that the ECtHR has in mind a right to counsel during pre-trial interrogation that is significantly stronger than that articulated in Miranda or its diluted postWarren Court progeny. First of all, the Court makes it clear that a waiver of the right to counsel must be unequivocal and cannot be presumed from the fact that the suspect answers questions after having acknowledged understanding of his rights. A valid waiver must be knowing and intelligent, which means that 'he could reasonably have foreseen what the consequences would bc. ${ }^{136}$ The ECtHR further held that it violates the right to counsel to continue questioning a suspect who has asked for counsel, unless the suspect has spoken to counsel or reinitiates the contact with police. ${ }^{137}$ It also found that subsequent confessions where the defendant did arguably waive his Miranda rights did not attenuate the taint of the previous confessions given without counsel. ${ }^{138}$ Finally, the ECtHR clearly linked the right to remain silent with the presumption of innocence and the notion that the prosecution must prove its case 'without resort to evidence obtained through coercion or oppression in defiance of the will of the accused. ${ }^{139}$

133 Ibid at 435-9.

134 Ibid at 438 , para 59.

135 However, in a later case, Oleg Kolesnik $v$ Lkraine, No 17551/02 (19 November 2009) (EHCR) at para 37, the ECtHR held that ECHR, supra note 8 , art 6 , had been violated in a case where the defendant signed a waiver of the right to counsel and confessed because he credibly alleged that police had cocrced him to waive the right.

136 Pishchalnikou of Russia, No 7025/04, (24 September 2009) at paras 76-7 (ECHR) [Pishchalnikov]. The ECtHR emphasized that the defendant was questioned about grave crimes such as murder after having been arrested for another crime and that only with counsel could he have assessed thc consequences of agreeing to the interrogation. Ibid at para 80. In contrast, the USSC recently ruled that an unequivocal waiver of Miranda rights, including the right to counsel, is no longer necessary and may be inferred from the fact that the defendant eventually answers questions; sec Berghuis $v$ Thompkins, 130 S Ct 2250 at 2260-2 (2010).

137 Pishchalnikor, ibid at para 79. The language seems plucked from Edwards, supra note 123 at 484.

138 Pishchalnikon, ibid at para 81-2. Here the ECtHR made a finding similar to that in Missouri $v$ Seibert, 542 US 600 at 601 (2004), which held that a Miranda waiver after a preceding statement taken in wilful violation of the Miranda rules could not be deemed to be knowing.

139 Zaichenku v Russia, № 39660/02 (18 February 2010) at para 38 (ECHR). 
The decisions in Salduz and its progeny are definitely a threat to the garde $a$ vue procedures in France and Belgium and are quickly leading to changes in other parts of Europe. ${ }^{140}$

\section{iii Exigent circumstances in relation to interrogations?}

The Salduz court admitted that there are possible restrictions on the right to counsel at the first interrogation: 'The question, in each case, has therefore been whether the restriction was justified and, if so, whether, in the light of the entirety of the proceedings, it has not deprived the accused of a fair hearing, for even a justified restriction is capable of doing so in certain circumstances. ${ }^{141}$ A typical example would be the restriction allowed in Code of Practice $\mathrm{C}$ of the Police and Criminal Evidence Act 1984 (PACE) in England and Wales, when the right to speak to a duty solicitor may be postponed if 'delay will involve an immediate risk of harm to persons or serious loss of, or damage to, property. ${ }^{142}$ The USSC has also recognized an exception to the need to give a suspect the Miranda warnings when 'prompted by a concern for the public safety.' ${ }^{\prime \prime 3}$

On the other hand, the ECtHR has made it clear that there are no exceptions to the prohibition against torture or inhuman and degrading treatment provided by ECHR article 3 even in the 'fight against terrorism and organized crime' or to save human life. ${ }^{144}$

\section{FUNDAMENTAL RIGHTS}

This summary suggests that, in addition to the right against torture and cruel and inhuman treatment, discussed above, the right to privacy within one's home and the right against self-incrimination also fall into the category of fundamental rights. Evidence obtained in violation of these rights should normally be excluded.

140 In early March 2011, the Belgian Senate approved a law providing for counsel before the first interrogation. 'Le Sénat adopte la loi Salduz: les droits des justiciables renforcés' (3 March 2011), online: rtbf.be <http://www.rtbf.be/info/belgique/ detail_le-senat-adopte-la-loi-salduz-les-droits-du-justiciable-renforces?id=5714303 $>$; in France, the Conseil constitutionnel ordered in April 2011 that Salduz be implemented in France, and lawyers stormed the jails demanding to represent their clients. Marion Isobel, 'Case Watch: Salduz fever sweeps Europe' Open Society Blog (26 April 2011), online: Open Society Foundations < http://blog.soros.org/2011/04/ case-watch-salduz-fever-sweeps-europe/ $>$.

141 Salduz, supra note 132 at 436 , para 52.

142 PACE, supra note 120 , art 6.6 (b) (i).

143 New York v Quarles, 467 US 649 at 656 (1984).

144 Gäfgen, supra note 53 at 23, 27 at para 87, 107. 
$\mathrm{v}$ Balancing by the courts

\section{A INTRODUCTION}

I have tried to articulate what violations would constitute fundamental or constitutional violations in a democratic country which respects human rights. This is clearly the case when interrogation methods are used that violate CAT or render a statement involuntary, and the consensus is growing for imposing a bright-line rule for interrogations in violation of the right to counsel. I would also make this claim in relation to violations of the right to privacy in one's domicile and private communications, when law enforcement authorities proceed without judicial authorization or probable cause in the absence of exigent circumstances. In some jurisdictions, the primary evidence and sometimes the actual 'fruits of the poisonous tree' are suppressed upon such a finding.

But this is not the case in the majority of jurisdictions, where courts tend to balance even clear constitutional violations against other important interests and often will suppress neither the direct nor the derivative evidence emanating from them. The use of any balancing test where fundamental rights have been violated, therefore, threatens to subordinate the right to other interests that have less (if any) constitutional significance; on the other hand, unlawfully obtained evidence that does not involve violations of fundamental rights may be admitted or excluded, depending on the balance of interests. In the rest of this section, I review the main tests and factors that courts have used in balancing interests. I will first examine three general tests, which I call the 'fair trial' test, the 'judicial integrity' test,' and the 'public interest' test. I will then examine separate factors used in these tests such as the 'good faith' of the violating officer, the seriousness of the violation, the question of whether the evidence was actually the 'fruit' of the violation, the importance of the evidence to determining the truth, and the seriousness of the offence for the proof of which the illegally gathered evidence has been proffered.

\section{B THE 'FAIR TRIAL' ASSESSMENT}

The PACE provides that

[i]n any proceedings the court may refuse to allow evidence on which the prosecution proposes to rely to be given if it appears to the court that, having regard to all the circumstances, including the circumstances in which the evidence was obtained, the admission of the evidence would have such an adverse effect on the fairness of the proceedings that the court ought not to admit it. ${ }^{145}$ 
In employing its 'fair trial' test, the ECtHR traditionally defers to domestic exclusionary practices. Thus, although the Court has found violations of the right to privacy under ECHR article 8 , in many cases involving illegal wiretapping or interception of private conversations, it has consistently held, that

[i] $t$ is not the role of the Court to determine, as a matter of principle, whether particular types of evidence - for example, unlawfully obtained evidence - may be admissible or, indeed, whether the applicant was guilty or not. The question which must be answered is whether the proceedings as a whole, including the way in which the evidence was obtained, were fair. This involves an examination of the 'unlawfulness' in question and, where violation of another Convention right is concerned, the nature of the violation found. ${ }^{146}$

When the Spanish Constitutional Court held in 1984 that evidence seized, in violation of the constitution had to be suppressed, it grounded the prohibition of use on (1) the violation of a fair trial with all the guarantees established by law (article 24 of the Spanish Constitution); (2) a denial of equality of arms, in the sense that the defence is not allowed to violate the law in order to produce evidence; and (3) a violation of the presumption of innocence, which in Spanish law restricts the prosecutor to the use of legally gathered evidence to rebut the presumption. ${ }^{147}$

Thus, whereas Spain finds a categorical violation of the right to a fair trial if the fruits of a violation of constitutional magnitude are used at trial, PACE article $78(1)$ gives the court what has been described in the literature as 'broad and unstructured' discretion to balance a plethora of factors against the illegality of police actions, such as the seriousness of the offence, good faith of the officers, the type of evidence and its reliability, the existence of corroborative evidence, the type of illegality, and the type of right infringed..$^{148}$ We can see here that the 'fair trial' criterion is flexible enough that, with so many factors in the balance, each judge can put his or her own stamp on what is a 'fair trial. ${ }^{\prime 19}$

146 Allan v United Kingdom (2003), 36 EHRR 12 at 143, 155-6, para 42. The first important case taking this approach was Schenck v Switzerland (1988), 13 EHRR 242 at 264, para 46. To my knowledge, the ECtHR has never found a violation of the right to a fair trial based solely on the use of evidence seized in violation of the right to privacy under ECHR, supra note 8, art 8 .

147 STC 114/1984 (29 November 1984), discussed in de Urbano Castrillo \& Torres Morato, supra note 128 at $41-2$; Aguilera Morales, supra note 84 at 84-8.

148 David Ormerod, 'ECHR and the Exclusion of Evidence: Trial Remedies for Article 8 Breaches?' (2003) Crim L Rev 61 at 64.

149 According to Andrew Ashworth, 'Excluding Evidence As Protecling Rights' (1977) Crim L Rev 723 ' [I]f courts are allowed simply to pick and choose the guiding 


\section{PRESERVING THE INTEGRITY OF THE COURTS}

Peter Duff correctly notes that, if exclusionary rules are to have any meaning they must be 'extrinsic' and not anchored in the 'intrinsic' emphasis on probative value/credibility. ${ }^{150}$ The notion of 'judicial integrity' is such an 'extrinsic' justification for exclusion; yet scholars differ as to its theoretical underpinnings, differentiating among (1) the 'disciplinary' model adopted by the United States which focuses on deterrence of unconstitutional police conduct; (2) the 'vindicatory' model, which focuses on protecting citizens' constitutional rights and would tend to automatic exclusion once a significant violation has been ascertained; ${ }^{151}$ and (3) the 'moral legitimacy' approach, which balances the seriousness of the constitutional violation and the harm to the public if a dangerous criminal were to go free. ${ }^{152}$

For the Mapp court, of course, the 'imperative of judicial integrity' was vindicatory and meant that 'the criminal goes free, if he must, but it is the law that sets him free. Nothing can destroy a government more quickly than its failure to observe its own laws, or worse, its disregard of the charter of its own existence.' ${ }^{153}$ The Court in Leon abandoned this high ground by equating judicial integrity with the exclusively disciplinary rationale, aimed only at deterring police and not at judicial errors. ${ }^{154}$

Article 24(2) of the Canadian Charter clearly proclaims judicial integrity as the basis for exclusion: '[W] here ... a court finds that evidence was obtained in a manner that infringed or denied any of the rights or freedoms guaranteed by this Charter, the evidence shall be excluded if it is established that, having regard to all the circumstances, the admission of it in the procecdings would bring the administration of justice into disrepute. ${ }^{155}$ In interpreting this provision, Canadian courts originally

principle(s) in the circumstances of any individual case, there is unlikely to be a consistent approach and a danger of the question of admissibility being left to the 'whim of the particular court' [Ashworth]; cited in Peter Duff, 'Admissibility of Improperly Obtained Physical Evidence in the Scottish Griminal Trial: The Search for Principle' (2004) 8 Ed L Rev 152 at 159 [Duff].

150 Ibid at 159 .

151 The New Zealand courts have rejected the deterrent rationale and focus exclusively on 'vindication of the right' that has been breached, though they still engage in balancing; see Richard Mahoney, 'Abolition of New Zealand's Prima Facie Exclusionary Rule' (2003) Crim L Rev 607 at 610. The Hawai'ian Supreme Court recognizes judicial integrity, deterrence, and the protection of privacy as foundations of its exclusionary rule. State v Bridges, 925 P (2d) 357 at 365 (Hawai'i 1996) [Mahoney].

152 Duff, supra note 149 at $160-74$.

153 Mapp, supra note 18 at 659 .

154 Leon, supra note 26 at 916.

155 Canadian Charter of Rights and Freedoms, Part I of the Constitution Act, 1982, being Schedule B to the Canada Act 1982 (UK), 1982 c 11. Article 35(5) of the Constitution of the Republic of South Africa, 1996 was patterned after the Canadian Charter and 
developed two separate tests to determine whether exclusion was appropriate. Under the first test, exclusion would result, regardless of the seriousness of the violation, if it had as a consequence that a suspect-defendant was 'conscripted' to produce evidence against himself. The second test focused exclusively on the seriousness of the violation such that a failure to exclude would bring the administration of justice into disrepute. Important factors here would be the intentionality of the violation and whether police acted in 'good faith' but not whether there might have been a hypothetical clean path to the evidence (i.e., inevitable discovery). ${ }^{156}$ Recently, the Canadian courts have moved to a simpler balancing test, which now includes the 'moral legitimacy' criterion. The test involves the weighing of three factors: (1) the severity of the violation; (2) the question of whether the admission of the evidence would bring the administration of justice into disrepute from the perspective of society's interest in respect for Charter rights; and (3) the effect of admitting the evidence on the public interest in having the case adjudicated on its merits. ${ }^{157}$

\section{THE PUBLIC IMPACT OH THE ADMISSIBILITY DECISION}

GCP-Taiwan (as amended in 2003), requires the court to balance 'the protection of human rights and the preservation of public interests' in deciding whether or not to exclude illegally gathered evidence. ${ }^{158}$ In 1950, the Scottish High Court developed a test which balanced '(a) the interest of the citizen to be protected from illcgal or irregular invasions of his liberties by the authorities, and (b) the interest of the State to secure that evidence bearing upon the commission of crime and necessary to enable justice to be done shall not be withheld from Courts of law on any merely formal or technical ground. ${ }^{159}$

But what is the 'public interest'? This could mean that the public would be appalled if evidence resulting from torture or pervasive

contains similar language, mandating exclusion if 'the admission of that evidence would render the trial unfair or otherwise be detrimental to the administration of justice'; see PJ Schwikkard \& SE van der Merwe, 'South Africa' in Craig M Bradley, ed, Criminal Procedure: A Worldwide Study, 2d ed (Durham, NC: Carolina Academic Press, 2007) 471 at 487-8 [Schwikkard \& van der Merwe].

156 Kent Roach, 'Canada' in Craig M Bradley, ed, Criminal Procedure: A Worldwide Study, 2d ed (Durham, NC: Carolina Academic Press, 2007) 57 at 71-2 [Roach].

157 See $R v$ Grant, 2009 SCG 32 at paras 95-7, [2009] SCR 353 [Grant]; $R v$ Harrison, 2009 SCC 34 at para 2, [2009] SCR 494. For a positive assessment of this change, see Don Stuart, 'Welcome Flexibility and Better Criteria from the Supreme Court of Canada for Exclusion of Evidence Obtained in Violation of the Canadian Charter of Rights and Freedoms' (2010) 16 Southwestern Journal of International Law 313.

158 Taiwan Constitution art 158-4 [CCP-Taiwan].

159 Laxurie y Muir, 1950 JC 19 at 26 (HCJ Scot). 
warrantless wiretapping were used in the courts. ${ }^{160}$ It could also refer to 'the public's interest in maintaining the integrity of the courts and in ensuring the observance of the law and minimum standards of propriety by those entrusted with powers of law enforcement,' as stated by the Australian High Court, which returns us to the interests of judicial integrity. ${ }^{161}$

In Leon, the USSC proclaimed,

The substantial social costs exacted by the exclusionary rule for the vindication of Fourth Amendment rights have long been a source of concern. Our cases have consistently recognized that unbending application of the exclusionary sanction to enforce ideals of governmental rectitude would impede unacceptably the truth-finding functions of judge and jury ... particularly, when law enforcement officers have acted in objective good faith or their transgressions have been minor, the magnitude of the benefit conferred on such guilty defendants offends basic concepts of the criminal justice system. ${ }^{162}$

Thus, the USSC posits a 'public interest' in 'having juries receive all probative evidence of a crime. ${ }^{163}$ More recently, the Court bemoaned the exclusionary rule's 'costly toll upon truth-seeking,' which consists in 'letting guilty and possibly dangerous defendants go free." ${ }^{164}$ Exclusion, for the USSC, is now a 'last resort' ${ }^{\prime} 65$ subject to a balancing test that pits the exclusionary rule's 'deterrence benefits' against its 'substantial social costs.' 166

With the USSC's disciplinary, cost-benefit approach, the 'intrinsic' emphasis on not losing probative evidence is pushing back the vindicatory interest in protecting constitutional rights, paving the way for a possible return to the old common-law presumption of admissibility of relevant evidence or its inquisitorial counterpart, which prioritized truth over rights.

\section{E APPLICATION OF THE BALANCING TESTS ONCE A CONSTITUTIONAL} VIOLATION HAS BEEN DETERMINED

i Was the constitutional violation excusable? Questions of 'good faith' and lack of intentionality

160 See Duff, supra note 149 at 155 , providing examples of this sort.

161 Ridgeway v the Queen, [1995] HCA 66, 184 CLR 19 at 38, cited to CLR in Craig M Bradley, 'Mapp Goes Abroad' (2001) 52 Case Western Reserve Law Review 375 at 380 [Bradley, 'Mapp'].

162 Leon, supra note 26 at $907-8$.

163 Murrays supra note 25 at 537.

164 Herring $v$ United States, 129 S Ct 695 at 697 (2009) [Herring].

165 Ibid at 700.

166 Hudson, supra note 33 at 591 . 
Once the German courts detcrmine that the interest violated is of constitutional magnitude, they next examine the gravity of the violation; that is, whether it was in conscious disregard of the law or only inadvertent or negligent. ${ }^{167} \mathrm{~A}$ similar test has been adopted by the Australian High Court, whereby the Court should take into consideration whether or not there was bad faith on the part of the police and also how easy it would have been to comply with the law. ${ }^{168}$ The Scottish courts also occasionally refer to whether there was bad faith on the part of the police in deciding whether to exclude. ${ }^{169}$ CCP-Netherlands gives the court discretion to exclude evidence and obligates it to 'take account of the interest that the breached rule serves, the gravity of the breach and the harm it causes. ${ }^{\prime} 70$

In 1998, the Spanish Constitutional Court admitted a 'good faith' exception to the otherwise categorical exclusionary rule codified in LOPJ-Spain article 11.1. ${ }^{171}$ It made the nice distinction between 'natural' and 'juridical' causation. The Court analysed the extent to which an illegal wiretap tainted the other evidence in terms of the right to a 'fair trial;' referring directly to the approach taken by the ECtHR in this respect. ${ }^{172}$ It analysed whether the violation was of a required 'intensity' and then used a balancing test to determine whether there was an 'anti-juridical' nexus between illegality and the derivative evidence. It determined that the violation was not so 'intense' due to the fact that the police did get a wiretap order and the violation was based on a lack of probable cause. The Court also noted that such an 'error' was not intentional and not grossly negligent, and that under the totality of the circumstances, the derivative evidence could be uscd. ${ }^{173}$ Here we see an incorporation of the 'good faith' rule articulated in Leon in relation to wiretaps, a step even the USSC has not yet taken.

In Leon, the USSC introduced the 'good faith' exception to the Fourth Amendment exclusionary rule in a case in which a magistrate erroneously issued a search warrant based on what a police officer believed in 'good faith' constituted probable cause. The USSC held that, though the Fourth Amendment was violated, excluding the illegally obtained evidence would only be appropriate to deter unlawful police conduct if the

167 Weigend, supra note 91 at 251.

168 Bunning v Cross, (1978) 141 CLR 54, cited in Bradley, 'Mapp,' supra note 161 at 380 [Bunning].

169 See Edgley v Barbour, 1994 SGCR 789 at 792 (HCJ Scot), cited in Duff, supra note 149 at 165.

170 Netherlands-CCP, supra note $44, \$ 359 \mathrm{a}(1)$.

171 STC 81/1998 (4 February 1998), online: <http://www.boe.es/aeboe/consultas/ bases_datos/doc.php?coleccion=tc\&id=SENTENCIA-1998-0081> [STC. 81/1998]

172 See Part IV-B below.

173 STC 81/1998, supra note 171. 
officer intentionally or recklessly submitted a clearly inadequate or 'bare bones' affidavit of probable cause or false evidence to the magistrate. ${ }^{174}$

The USSC has also extended the 'good faith' exception to other areas where the magistrate erred, such as where the search warrant itself contained an erroneous or inadequate description of the things to be seized or the places to be searched ${ }^{175}$ or where an unlawful detention was based on erroneous court records. ${ }^{176}$ Finally, however, the Court has lowered the bar recently to allow admission of evidence which was gathered when the police were guilty of 'isolated negligence' in believing there was probable cause. ${ }^{177}$

Since the assessment of probable cause - that is, a 'fair probability' that a crime has been committed or that evidence of that crime is to be found in a particular place - is a value judgment based on the 'totality of the circumstances,' I believe that a narrow exception can be allowed in borderline cases where 'reasonable minds may differ on the question whether a particular affidavit establishes probable cause, ${ }^{, 178}$ when the officer has followed the search warrant procedure and submitted the casc to an impartial magistrate. I also believe that 'good faith' could save evidence derived from police procedures which were allowed by law or high-court jurisprudence when they were performed but where the standards became stricter after the measure was undertaken. ${ }^{179} I$ believe the exception for police negligence is, however, going too far. I agree with Justice Ginsburg's dissent in Herring that tort liability for negligence is considered to deter careless conduct in citizens, and if the Fourth Amendment exclusionary is meant to deter, it should encompass negligent conduct as well. ${ }^{80}$

\section{ii Was the evidence the 'fruit' of the constitutional violation?}

a Introduction

Even if a system recognizes the extension of the exclusionary rule to derivative evidence, the question still remains as to whether the evidence to be admitted really owes its existence to the constitutional violation; that

174 Leon, supra note 26 at $915-23$.

175 Massachusetts $v$ Shepard, 468 US 981 at 988-90 (1984), decided on the same day as Leon, supra note 26.

176 Arizona v Evans, 514 US 1 at 14-5 (1995).

177 Herring, supra note 164 at 702 .

178 Loon, supra note 26 at 914 .

179 For instance, the USSC recently limited the scope of a search incident to an arrest of a vehicle; see Arizona v Gant, 129 S Ct 1710 (2009). Several courts have refused to suppress evidence gathered in searches which abided by the earlier rule but violated the new Gant strictures; see State v Baker, 229 P (3d) 650 at 668 (Utah 2010); State v Daniel, 242 P (3d) 1186 at 1195 (Kan 2010); United Stales $v$ Davis, 598 F (3d) 1259 at 1267 (11th Cir 2010); United States v Buford, 632 F (3d) 264 at 276-7 (6th Cir 2011).

180 Herring, supra note 164 at 708 (Ginsburg, dissenting). 
is, is actually its 'fruit.' And it is here that the famous exception of 'attenuated taint' and its closely related subcategories 'inevitable discovery' or 'independent source' are invoked to admit arguably dcrivative evidence.

Each of these exceptions has been recognized and applied by the Spanish courts, despite Spain's categorical exclusionary rule in relation to derivative evidence. ${ }^{181}$ Since the aforementioned Constitutional Court decision in 1998, Spain's courts now engage in a balancing test to determine whether to exclude the fruits of a constitutional violation and the test is framed in terms of a limitation on the doctrine of the 'fruits of the poisonous tree.' An exception to the otherwise categorical rule can exist 'even when there is a factual causal nexus between the illegality and the evidence, if the causal link is not based in the illegality' (is not 'anti-juridical'). In assessing the existence of a legally relevant connection, the following elements should be taken into account: (a) what the significance was of the constitutional infringement; (b) what importance the evidence had for proving guilt; (c) whether there was a hypothetical clean path to discover the evidence (i.e., inevitable discovery); (d) whether the right violated requires special protection; and (e) whether the violating officers acted intentionally or erred in good faith and thus whether exclusion is necessary for deterrent purposes. ${ }^{182}$

I will now discuss how courts approach the issue of 'fruits' in deciding whether to suppress fruits of both privacy violations and unconstitutional confessions.

\section{b Fruits of illegal dwelling searches}

\section{(1) Independent source and inevitable discovery}

The courts will generally allow evidence that has been discovered through an illegal 'search' if it is actually 'seized' by independent legal means. ${ }^{183}$ The courts will also admit evidence which is seized illegally if it would inevitably have been discovered through legal means. ${ }^{184}$ The doctrine of

181 See the decision of the Spanish Supreme Court in STS (5June 1995) RJ No 4538, 6058 at 6060; for English translation, see Thaman, Criminal Procedur, supra note 37 at 118-9.

182 STS 9/2004 (19 January 2004), online: <http://sentencias.juridicas.com/index. php $>$.

183 The doctrine of 'independent source' is applied in cases where there have been two searches, an illegal one and a legal one, independent of the illegality. It is applied, for instance, when police discover the presence of evidence illegally but actually scize it pursuant to a search warrant based on information they possessed before the illegal search; see Segura $v$ United States, 468 US 796 at 805 (1984); Murray, supra note 25 at 537.

184 This doctrine of 'inevitable discovery' is applied where there is only one search and seizure but other investigative procedures independent of the illegality would have discovered the evidence legally. Williams, supra note 24 at 444 . The Germans call this the 'hypothetical independent source' or 'hypothetical clean path'; Weigend, supra note 91 at 253 . 
'inevitable discovery,' however, can serve as a gaping loophole in constitutional protections if interpreted in too broad a manner. Some American courts have recognized this exception if the police, who had probable cause, were already in the process of getting a search warrant when they erroneously but in good faith felt that exigent circumstances existed which allowed them to make a warrantless entry. ${ }^{185}$ However, the most dangerous extension of this notion of a 'hypothetical independent source' is when the court allows the introduction of evidence because probable cause existed and a judge would have approved a warrant application had it been submitted. ${ }^{186}$ The German Courts have routinely used this latter rationale and almost never exclude the direct fruits of warrantless searches. ${ }^{187}$

\section{(2) The seizure is not a fruit of the unlawful search}

In overseas jurisprudence one finds doctrines which sever the causal connection between a constitutional illegality and its 'fruits' in ways unknown in the United States. One of these is the notion that seizures are conceptually independent of searches and that if the seizure is 'legal' then the nexus of illegality has been attenuated. Another is that a seizure that is a causal result of an illegal search can, nevertheless, be attenuated by judicial balancing of other factors.

It is a doctrine firmly entrenched in Italy and accepted by courts in Germany that the seizure of drugs, for instance, is not the fruit of a clearly unconstitutional search, even where the express object of the search was to find those self-same drugs. The Italian courts reason that, since CPP-Italy section 253(1) requires the police to seize the corpus delicti of a crime (that is, fruits, instrumentalities, and contraband), then this legal seizure cannot be vitiated by an antecedent unconstitutional search, be it without probable cause or judicial authorization. ${ }^{188}$ The courts have held that searches and seizures have different juridical

185 United States v Cabassa, 62 F (3d) 470 at 473 (2d Cir 1995); United States v Whitehorn, 829 F (2d) 1225 at 1232-3 (2d Cir 1987), with respect to a search warrant signed after the search; United Slates $v$ Curtis, 931 F (2d) 1011 at 1013 (4th Cir 1991).

186 The overwhelming majority of US courts have rejected this argument, for it would make the warrant requirement meaningless. United States v Johnson, 22 F (3d) 674 at 680 (6th Cir 1994); United States v Echegoyen, 799 F (2d) 1271 at 1279 (9th Cir 1986); Slale v Handtmann, $437 \mathrm{NW} 2 \mathrm{~d} 830$ at 838 (ND 1989); United States v Broum, $64 \mathrm{~F}$ (3d) 1083 at 1085 (7th Cir 1995).

187 See Ransiek, supra note 95 at 566. In 1989, the German Supreme Court held that the evidence found in an unconstitutional search will be admissible as long as it is otherwise legally seizable (i.e., is contraband, fruits, or instrumentalities of crime) and a judge would have issued a search warrant had the police sought one; see Weigend, supra note 91 at 252.

188 Italian Supreme Court (27 March 1996) Giust Penale 138, 140, 144-5 (1997); for English translation, see Thaman, Criminal Procedure, supra note 37 at 122-4. 
presuppositions and functions and cannot be viewed as linked due to their convergence in reality. ${ }^{189}$ As was noted in Section III above, the doctrine of 'fruits of the poisonous tree' applies only to 'nullities' when expressly provided by statute and not to the general exclusionary rule in CCP-Italy section $191 .^{190}$ This doctrine is baffling, because the Italian literature, like the Spanish, asserts that 'nullities' relate only to nonconstitutional violations in the gathering of evidence, whereas 'nonusability' applies only to violations of fundamental rights. ${ }^{191}$

By separating an unlawful search, which is a tool to find evidence to use in a criminal case, from its object, the evidence sought, the Italian and German courts ignore the plain meaning of their constitutional prohibitions on unwarranted searches in order to achieve a goal, the conviction of a guilty person at any cost, which is no longer the purported goal of criminal procedure. It is clear that the prohibition of the violation of privacy of the dwelling is not only rooted in the protection of privacy, but also constitutes a limitation on the ability of the state to gather information or seize evidence in those spaces. Search and seizure cannot be logically separated into different actions with different motivations. ${ }^{192}$

\section{c Fruits of unconstitutional interceptions of confidential conversations} Unlike in America, where the fruits of a violation of the wiretap statute are explicitly inadmissible, the approach in Europe is less rigorous. In Germany, for instance, the testimony of witnesses who were discovered through an illegal interception has been admitted at trial. ${ }^{193}$ Although CCP-Italy section 271(1) mandates 'non-usability' of illegally intercepted conversations, CCP-Italy section 271(3) makes an exception for physical fruits which can prove corpus delicti. There is also no restriction on using the contents of 'non-usable' conversations to further the investigation, discover new crimes, and so on. ${ }^{194}$ New wiretaps may also be based on the information gained from antecedent illegal ones. ${ }^{195}$

189 Italian Supreme Court (24 April 1991) Decision No; cited in Conso \& Grevi, supra note 43 at 550.

190 See Decision No 332/2001, supra note 43; c.f. Conso \& Grevi, supra note 43 at 339.

191 Giuseppe Luigi Fanuli, Inutilizzabilità e nullitá della prova nel giudizio abbreviato, nel 'patteggiamento' e nell'istituto della acquisizione degli atti su accordo delle parti (Milan: Giuffre, 2004) at 5-6.

192 Ransiek, supra note 95 at 568. At least one section of the Italian Supreme Court has rejected the prevailing doctrine and recognizes a strict functional relationship between the act of searching and the seizure. Italian Supreme Court (13 March 1992) Decision No; cited in Conso \& Grevi, supra note 43 at 550.

193 See Weigend, supra note 91 at 253.

194 Franco Cordero, Procedura penale, 5th ed (Milan: Giuffrè, 2000) at 804.

195 Conso \& Grevi, supra note 43 at 399. 
Until the advent of the new approach of the Spanish Constitutional Court in $1998,{ }^{196}$ physical evidence found as a result of an unconstitutional wiretap or bugging was routinely suppressed in accordance with IOPJ-Spain section 11.1 and could not be used at trial. ${ }^{197}$ For example, in one case police used a scanner to intercept cell-phone conversations without having obtained judicial authorization. The information gathered led to an arrest and the search incident thereto uncovered drugs. The Supreme Court held that the drugs were fruit of the poisonous tree and could not be used. ${ }^{198}$ Since the advent of the new case law, however, the decision has depended on the new balancing test mentioned above. ${ }^{199}$ In the seminal 1998 case, the Spanish Constitutional Court used the doctrine of inevitable discovery to dissociate the arrest of the defendant in possession of drugs from an unconstitutional wiretap by arguing that the defendant had already been under heavy police surveillance and the arrest was therefore not sufficiently tainted by the antecedent illegality. ${ }^{200}$

d 'Fruits' of 'involuntary' confessions which may or may not be the product of cruel, inhuman, or degrading treatment

I submit, based on the analysis in Part III-A above, that any fruits, even physical evidence, of confessions induccd by torture or cruel, inhuman, or degrading treatment must be suppressed, provided that the taint has not been attenuated. The USSC has also indicated that the 'fruits of the poisonous tree' of 'involuntary' confessions which were not induccd by cruel, inhuman, or degrading treatment would also not be usable in a criminal trial. Thus, in Oregon $v$ Elstad ${ }^{201}$ the Court held that a voluntary confession following proper section 11.1 warnings ${ }^{202}$ would be subject to exclusion if it followed on the heels of a confession deemed to be involuntary under the due process analysis. In Patane, ${ }^{203}$ a plurality of the Court also said that physical evidence would be subject to exclusion if found as a result of a 'coerced' confession. Because the USSC based its reluctance to apply the 'fruits of the poisonous tree' doctrine to Miranda violations on their supposed sub-constitutional,

196 STC $81 / 1998$, supra note 171.

197 See Juan-Luis Gómez Colomer, 'La intervención judicial de las comunicaciones telefónicas a la luz de la jurisprudencia' (1998) 97 Revista Jurídica de Catalunya 145 at $162-6$.

198 STS 137/1999 (8 February 1999), online: <http://sentencias.juridicas.com/index. php $>$.

199 See text accompanying note 173 supra.

200 Scc STC 81/1998, supra note 171.

201470 US 298 at 340 (1985).

202 On section 11.1 warnings, see Miranda, supra note 22.

203 Supra note 64 at 632. 
'prophylactic' character, it would follow, therefore, that a clear constitutional violation of due process resulting in an involuntary confession would necessarily require exclusion of the 'fruits,' whether they be in the form of subsequent confessions or physical evidence. ${ }^{204}$ In addition, no evidence derived in any way from a statement compelled through a grant of immunity may be admissible in a trial of the person who was granted immunity. ${ }^{205}$

In some jurisdictions, however, the fruits of involuntary statements may be used. Although PACE section 76(2) (a) provides that a confession 'may' be rendered inadmissible "where it is the product of "oppression," "206 section 76(4-6) of the same statute allows for the admission in evidence of any facts or physical evidence which were found as a result of the inadmissible confession. ${ }^{207}$ Argentine courts have also allowed the use of information from involuntary confessions to further the investigation..$^{208}$

e Fruits of 'unknowing' confessions taken in violation of the right to counsel or without admonitions as to the right to silence

Following the Patane decision, ${ }^{209}$ there is no bar in the US federal courts to using physical evidence gathered as a result of a violation of the Miranda rule. Many European countries take a similar approach. For instance, the Italian courts do not recognize the doctrine of 'fruits of the poisonous tree' for physical evidence or witnesses discovered through otherwise unlawful confessions. ${ }^{210}$ In Germany, which has given Miranda warnings constitutional status, the courts do not extend the evidentiary prohibition to the 'fruits' of a confession taken without the proper warnings, whether in the form of physical evidence or subsequent confessions. ${ }^{211}$

204 Supporting this interpretation, LaFave et al, supra note 53 at 543.

20518 USC $\$ 6002$ : 'The prosecution has a burden to prove the evidence it uses is derived from a legitimate source wholly independent of the compelled testimony.' See also Kastigar v United States, 406 US 441 at 460 (1972).

206 PACE, supra note 120.

207 Ibid. Compare ibid at para 76(5), which provides, nevertheless, that the jury shall not be told that the 'facts' were derived from the statements of the defendant. Duff, supra note 149 at 152, alleges that there are no English cases upholding the suppression of physical evidence.

208 Alejandro D Carrió \& Alejandro M Garro, 'Argentina' in Craig M Bradley, ed, Criminal Procedure: A Worldwide Study, 2d ed (Durham, NC: Carolina Academic Press, 2007) 3 at 32-3.

209 Supra note 64.

210 Elizabeth MT Di Palma, 'Riflessioni sulla sfera di operativitá della sanzione di cui all'art. 191 cpp' in Vincenzo Perchinunno, ed, Percorsi di Procedura Penale. Dal garantismo inquisitorio a un accusatorio non garantito (Milan: Giuffrè, 1996) at 113 at 115.

211 Weigend, supra note 91 at 261. 
Some US state courts, however, have suppressed physical evidence resulting from a Miranda violation, whether or not the violation was intentional or inadvertent. ${ }^{212}$

In Canada, police are not constitutionally required to advise detained suspects of the right to silence before questioning them, but section 10 (b) of the Charter does accord arrested persons the right to attempt to contact counscl before being interrogated. ${ }^{213}$ If the right to counsel has been violated, however, and derivative evidence is found that could not have been found but for the violation, the Canadian courts consider this to be 'conscripted' cvidence and have traditionally suppressed it. Thus, if a suspect points out incriminating evidence in his own house, which would have been searched anyway, this would be admissible; but if the accused, while being denied the right to counsel, informs police that the murder weapon is at the bottom of a frozen river, this must be suppressed. ${ }^{214}$ Whether the 'conscription' doctrine is still viable is questionable, since the Canadian Supreme Court recently adopted a new approach to exclusion in two 2009 cases. ${ }^{215}$

\section{F BALANGING THE QUALITY OR IMPORTANCE OF THE EVIDENCE \\ i Introduction: Distinguishing among different kinds of evidence}

Prior to 2002, in New Zealand there was a rebuttable presumption that illegally gathered evidence was inadmissible. The New Zealand Court of Appeal, however, adopted a new, multi-factor 'fairness' test in 2002 which gives the trial judge broad discretion in deciding whether to exclude illegally gathered evidence and provides a list of criteria to be weighed, including the 'seriousness of the offense' and the 'importance of the evidence. ${ }^{\prime \prime 16} \mathrm{~A}$ similar test was adopted by the Australian High Court, which required trial courts to consider the question of whether there was bad faith on the part of the police, the importance of the evidence, the seriousness of the offence, and the ease with which the law might have been complied with. ${ }^{217}$

212 Commonwealth $v$ Martin, $827 \mathrm{NE}$ (2d) 198 at 215 (Mass 2005); State v Knapp, $700 \mathrm{NW}$ (2d) 899 at 905-6 (Wis 2005); State v Peterson, $923 \mathrm{~A}$ (2d) 585 at 588-91 (Vt 2007); State v Vondehn, 236 P (3d) 691 at 695 (Or 2010).

213 Roach, supra note 156 at $75-7$.

214 Ibid at 71.

215 See Grant, supra note 157 at para 16, where the court balanced a non-egregious unlawful detention and questioning by virtue of which the defendant was 'conscripted' to admit possession of a gun against the importance of the rights impinged on thereby and the importance of the physical evidence to determine the truth of the charges and admitted the gun.

$216 R v$ Shaheed, [2002] 2 NZI R 377 (CA); cited in Mahoney, supra note 151 at 607.

217 Bunning, supra note 168 at 380 . 
The right to privacy in Germany and some other countries is grounded in the right to human dignity and most importantly the 'right to develop one's personality, ${ }^{218}$ This approach has led to declaring certain items non-seizable, even where the government has probable cause that they would be material to prove guilt in a criminal case. In Germany, for instance, this protection extends to personal diaries ${ }^{219}$ and to a person's spoken words when surreptitiously recorded by another, whether the recorder is or is not a state official. ${ }^{220}$

This doctrine is reminiscent of the old 'mere evidence' doctrine of the USSC which was overruled in $1967 .{ }^{221}$ According to that doctrine, the government only had a right to seize the corpus delicti of crime; that is, objects to which it had a superior title, such as fruits and instruments of crime, and contraband. Personal papers were protected unless they were instruments of crime. ${ }^{.29}$ In fact, to scarch for and seize a person's words, even where put to paper or uttered under no compulsion, was considered to be tantamount to compelling self-incrimination. As the Boyd court noted, '[W]e have been unable to perceive that the seizure of a man's private books and papers to be used in evidence against him is substantially different from compelling him to be a witness against himself. ${ }^{223}$

The now overruled 'mere evidence' rule and the current German limitations on using highly personal evidence to prove guilt are examples, not merely of prohibitions on 'use' due to the irregular or illegal methods of seizure, ${ }^{224}$ but of prima facie intrinsic prohibitions on the seizure of what may be highly probative evidence.

\section{ii Evidence of questionable reliability}

Coerced or otherwise involuntary confessions were traditionally excluded in the United States due to their lack of credibility rather than on constitutional grounds. ${ }^{225}$ Today, even potentially probative evidence may be

218 Const-Germany, supra note 92 , art $2(1)$

219 See Decision of German Supreme Court of 21 February 1964, 19 BGHSt 325 at 326-8 (1964); for English translation, see Thaman, Criminal Procedure, supra note 37 at 82.

220 See Decision of German Supreme Court of 14 June 1960, 14 BGHSt 358 at 359-60, 364-5 (1960); for English translation, see Thaman, Criminal Procedure, supra note 37 at $72-3$.

221 Warden, supra note 100 at $309-10$.

222 Boyd v United States, 116 US 616 at 628 (1886); Weeks, supra note 14 at 391-2.

223 Boyd, ibid at 633 . Note the similarity with the now out-dated Canadian exclusionary rule based on constitutional violations which 'conscript' the defendant to give evidence against himself. For a similar comparison of a subpoena duces tecum with an involuntary confession, see Beling, supra note 28 at 14.

224 On the distinction between Beweiserhebungsverbot (evidentiary gathering prohibition) and Beweisverwerlungsverbot (evidentiary use prohibition), see Claus Roxin, Strafverfahrensrecht: ein Studienbuch, 24th ed (Munich: Beck, 1995) at 164.

225 Hopt $v$ Territory of Utah, 110 US 574 at 585 (1884). 
excluded if the judge decides that its prejudicial nature outweighs its probative value. ${ }^{226}$

A number of post-Soviet codes have exclusionary rules which limit exclusion to situations where the violation influenced or could have influenced the credibility of the evidence. ${ }^{227}$ Such emphasis on the credibility of the evidence also constitutes one prong of the tests which have been adopted by the International Criminal Tribunals for the Former Yugoslavia (ICTY) and Rwanda (ICTR) and for the International Criminal Court (ICC). Rule 95 of the ICTY Rules of Procedure and Evidence provides: 'No evidence shall be admissible if obtained by methods which cast substantial doubt on its reliability or if its admission is antithetical to, and would seriously damage, the integrity of the proceedings. ${ }^{228}$ Identical language was incorporated into section $69(7)$ of the Rome Statute for the International Criminal Court. ${ }^{229}$

Exclusionary rules based on the questionable reliability of evidence are unremarkable, for courts should generally only admit reliable and relevant evidence or, at the least, should prevent judges from relying on questionable evidence when formulating the reasons for their decisions.

\section{iii Physical evidence that proves corpus delicti}

We have discussed how, in Italy the police duty to seize contraband, fruits, and instrumentalities of crime - that is, the corpus delicti - breaks the nexus between a patently unconstitutional search and its intended fruits and allows the use of the cvidence collected. ${ }^{230}$ The other side of this equation is that 'mere evidence' discovered in a patently illegal search would be 'non-usable,' much as it was under Boyd even following a warranted search based on probable cause.

The unwillingness of most courts to suppress physical evidence which is a fruit of a violation of the right to privacy or the Miranda rules and of some to do so when the evidence is the fruit of an unconstitutional wiretap or an involuntary confession speaks to the preponderance of truth-finding over constitutional rights, at least when dealing with the

226 Fed R Evid 403; Cal Evidence Code $\$ 352$.

227 CCP-Armenia at para 105 (footnote info needed on three of these). Similar language is used in CCP-Azerbaijan $\$ 125$ (2)(1); CCP-Moldova $\S 94(2)$; and CCP-Turkmenistan $\S$ 125.

228 UN, International Tribunal for the Prosecution of Persons Responsible for Serious Violations of International Humanitarian Law Committed in the Territory of the Former Yugoslavia since 1991, Rules of Procedure and Evidence, UN Doc IT/32/Rev 40 (2007). See also International Criminal Tribunal for Rwanda, Rules of Procedure and Evidence, adopted 5 July 1996, online: <http://www.unictr.org/Portals/0/ English\%5CI egal\%5CEvidance\%5CEnglish\%5C050796e.pdf $>$.

229 The Rome Statute of the International Criminal Court, UNGAOR, 53d Sess, UN Doc A/ CONF183/9 (1998).

230 See text accompanying note 188 supra. 
most reliable of evidence. This balancing is justified by some courts with the assertion that the admission of physical evidence can never violate the right to a fair trial because it is not really the 'fruit' of the violation, nor dependent thereon, having pre-existed the violation. ${ }^{231}$

\section{G THE GRAVITY OF THE GRIME WHICH IS BEING PROSECUTED}

Beling's treatise on evidentiary prohibitions clearly provided for more liberal admissibility of illegally seized evidence in capital cases than in less serious ones: '[T] he interest in solving high treason or a murder is infinitely greater than the interest in investigating and punishing a cyclist who drives on the wrong side of the road, or a sassy young man who gives his desire for singing too long a rein during night time hours. ${ }^{932}$ Beling's approach has now been squarely adopted by the German courts. Thus, even if a court is dealing with a grave violation of the right to develop one's personality which would normally lead to exclusion of a diary, for instance, the court must still weigh the seriousness of the crime charged before deciding whether to exclude. ${ }^{233}$

Andrew Ashworth has, in my view correctly, asserted that the seriousness of the charges facing the defendant should never go into the balancing process because the more serious the charge, the more detrimental will be the introduction of the evidence to the defendant due to the more severe punishment awaiting him. ${ }^{234} \mathrm{~A}$ compromise position here would be to mandate a reduction of punishment if the state violated the constitution in order to bring someone to justice. ${ }^{235}$

In another context, I have suggested that all interrogations should take place only after counsel has been provided and that confessions should be negotiated, much like plea-bargains: the defendant could agree to help the state in proving guilt but only after having negotiated a discounted punishment. The truth might better be ascertained through a grant of leniency than through the typical psychological coercion of custodial interrogation. ${ }^{236}$ Criminal codes could also provide statutory

231 This rationalization is employed in South Africa; see Schwikkard \& van der Merwe, supra note 155 at 488.

232 Beling, supra note 28 at 35 .

233 The German Supreme Court allowed use of a diary in a brutal rape-murder case but not in a perjury case; Thaman, Criminal Procedure, supra note 37 at 113.

234 Ashworth, supra note 148 at 732 [cited in Duff]; discussed in Duff, supra note 149 at 169-71.

235 This is allowed under CCP-Netherlands, supra note $44, \S 359 \mathrm{a}$ and is suggested by some US commentators; see Guido Calabresi, 'The Exclusionary Rule' (2003) 26 Harv JL \& Pub Pol'y 111 at 116.

236 Stephen C Thaman, 'Gerechtigkeit und Verfahrensvielfalt: Logik der beschleunigten, konsuellen und vereinfachten Strafprozessmodelle' in Stefan Machura \& Stefan Ulbrich, eds, Recht-Gesellschafl-Kommunikation: Festschrift für Klaus F Röhl (Baden Baden, Germany: Nomos, 2003) 314. 
mitigation whenever the use of unconstitutionally acquired evidence is required to prove guilt. In other words, the maximum punishment should only be allowable if the state can prove guilt without any help from the defendant, whether obtained voluntarily or involuntarily.

\section{H APPROPRIATE BALANCING}

The balancing doctrines discussed in this part of the paper are applied to illegal evidence gathering of all kinds. As argued above, they should not be applied where the illegality in question involves a violation of fundamental constitutional rights. Nonetheless, these doctrines are useful in considering appropriate balancing in cases where an illegality of lesser significance has occurred. In such cases, factors relevant to the seriousness of the violation (e.g., good or bad faith) can be balanced against factors relevant to the effect of the evidence on the trial (e.g., trial fairness, reliability). However, for the reasons given by Ashworth, the seriousness of the offence should not be a factor.

vI Conclusion

Only a few jurisdictions, notably those which have recently emerged from under totalitarian or authoritarian regimes (former Soviet and Yugoslav republics, Turkey, Latin American countries) have foreclosed all balancing in relation to the use of any evidence which was gathered illegally, whether or not the illegality was of constitutional proportions. Otherwise, the international community has clearly prohibited any balancing in relation to statements obtained through torture, or cruel, inhuman, and degrading treatment and appears to be moving in that direction in relation to statements given either involuntarily or in the absence of counsel. Although most countries will suppress confidential communications that were obtained in violation of wiretap legislation, a blanket exclusionary rule which includes fruits, such as exists in the US legislation, is not yet a commonplace in relation to either illegal wiretaps or involuntary or counsel-less statements.

Once a country advances from a police state to an entrenched democratic society, should we allow more balancing (i.e., tolerate more police lawlessness) or less? Should we extend categorical exclusion, including that of 'fruits,' to privacy and Miranda violations or even admit of balancing in relation to what are considered to be more serious violations? The categorical exclusionary rule of LOPJ-Spain section 11.1 was arguably still a reaction to the abuses of the Francoist police but has now given way to a balancing test. In the United States, the harsh language of Weeks condemning widespread police violation of rights led to seemingly categorical exclusionary rules in Mapp and Miranda, but the recent cases, which propose doing more balancing, seem to intimate that our police have 
now developed to such an extent that the old toughness is no longer required. ${ }^{237}$ But if police have become more professional, shouldn't they be aware of constitutional rules and follow them? Or do our modern constitutional rules prevent police from solving crimes or make it too time consuming?

Once such a violation of constitutional importance has been ascertained, there should be a presumption that any evidence directly or indirectly gathered as a result of the violation should be excluded. Valid exceptions, such as for good faith mistakes or emergency situations, should be narrowly construed in the way I have argued above. 'Fruits of the poisonous tree,' even physical evidence, should be excluded when the taint of the violation has not been attenuated, there is no true independent source, and the evidence would not inevitably have been discovered.

The seriousness of the crime under investigation should play a role in the assessment of whether emergency or exigent circumstances will obviate the necessity to secure a warrant or administer Miranda warnings but should not be an omnibus reason to admit evidence where there has been a clear and unforgiveable constitutional violation. The area of 'good faith' of the violating official should be limited to cases where the officer was using what were formerly accepted practices at the time of the investigative measure that were subsequently deemed to violate constitutional principles, or where a search warrant was obtained based on evidence which was close to being 'probable cause.' A police officer who acts negligently is not acting in 'good faith,' especially in a case like Herring, where police were negligent in looking for a pretext to arrest someone as to whom they had no reasonable suspicion. ${ }^{238}$

Finally, the importance of the evidence to convict the defendant should never be a factor. The ECtHR has consistently ruled that the use of evidence gathered in violation of the defendant's right to confront her accusers, which is protected by ECHR article 6(e)(d), will violate the 'fair trial' right of ECHR article 6 if it is the main evidence of guilt but not necessarily if it is only used to corroborate other substantial evidence of guilt.239 The ECtHR has taken this approach in relation to the violation of the right to counsel in Salduz and I believe they should extend it to violations of the right to privacy as well.

The area where true judicial balancing should have free rein, is whcre. the violation is truly not of constitutional significance, such as errors in

237 See for instance $H u d s o m$, supra note 33 at 598-9.

238 Herring, supra note 164 at 698 , noring that the reason for stopping the defendant was that he was 'no stranger to law enforcement.'

239 See discussion of ECtHR case law in Thaman, Criminal Procedure, supra note 37 at $129-35$. 
the execution of a search or wiretap warrant otherwise based on probable cause. Here, the seriousness of the violation can be weighed against the seriousness of the offence, the intentionality of the violations, and so on.

When balancing is allowed, it should also not be undertaken by the trial judge, especially in those systems bascd in the civil law, where the trial judge is considered to be an investigator of the material truth of the charges. A judge with such inquisitorial duties will intentionally or instinctively give priority to the principle of matcrial truth in exercising the Herculean balancing act and neglect the equally important role as constitutional guarantor. Therefore, if judicial balancing is to persist, it should be carried out by a neutral judge of the investigation, or liberty judge, and not the trial judge or investigating magistrate, who is also duty-bound to seek truth. 